\title{
Mechanism of Producing Metallic Nanoparticles, with an Emphasis on Silver and Gold Nanoparticles, Using Bottom-Up Methods
}

\author{
Basil Raju Karimadom (D) and Haya Kornweitz *(D) \\ Chemical Sciences Department, Ariel University, Ariel 4077625, Israel; basilr@ariel.ac.il \\ * Correspondence: hayak@ariel.ac.il
}

check for

updates

Citation: Karimadom, B.R.;

Kornweitz, H. Mechanism of

Producing Metallic Nanoparticles,

with an Emphasis on Silver and Gold

Nanoparticles, Using Bottom-Up

Methods. Molecules 2021, 26, 2968.

https://doi.org/10.3390/

molecules26102968

Academic Editor:

Mohammed Baalousha

Received: 8 April 2021

Accepted: 14 May 2021

Published: 17 May 2021

Publisher's Note: MDPI stays neutral with regard to jurisdictional claims in published maps and institutional affiliations.

Copyright: (c) 2021 by the authors. Licensee MDPI, Basel, Switzerland. This article is an open access article distributed under the terms and conditions of the Creative Commons Attribution (CC BY) license (https:// creativecommons.org/licenses/by/ $4.0 /)$.

\begin{abstract}
Bottom-up nanoparticle (NP) formation is assumed to begin with the reduction of the precursor metallic ions to form zero-valent atoms. Studies in which this assumption was made are reviewed. The standard reduction potential for the formation of aqueous metallic atoms$\mathrm{E}^{0}\left(\mathrm{M}^{\mathrm{n}+}{ }_{\mathrm{aq}} / \mathrm{M}^{0}{ }_{\mathrm{aq}}\right)$-is significantly lower than the usual standard reduction potential for reducing metallic ions $\mathrm{M}^{\mathrm{n}+}$ in aqueous solution to a metal in solid state. $\mathrm{E}^{0}\left(\mathrm{M}^{\mathrm{n}+}{ }_{\mathrm{aq}} / \mathrm{M}^{0}{ }_{\text {solid }}\right) \cdot \mathrm{E}^{0}\left(\mathrm{M}^{\mathrm{n}+}{ }_{\mathrm{aq}} / \mathrm{M}^{0}{ }_{\mathrm{aq}}\right)$ values are negative for many typical metals, including $\mathrm{Ag}$ and $\mathrm{Au}$, for which $\mathrm{E}^{0}\left(\mathrm{M}^{\mathrm{n}+}{ }_{\mathrm{aq}} / \mathrm{M}^{0}{ }_{\text {solid }}\right)$ is positive. Therefore, many common moderate reduction agents that do not have significantly high negative reduction standard potentials (e.g., hydrogen, carbon monoxide, citrate, hydroxylamine, formaldehyde, ascorbate, squartic acid, and $\mathrm{BH}_{4}{ }^{-}$), and cannot reduce the metallic cations to zerovalent atoms, indicating that the mechanism of NP production should be reconsidered. Both AgNP and AuNP formations were found to be multi-step processes that begin with the formation of clusters constructed from a skeleton of $\mathrm{M}^{+}-\mathrm{M}^{+}(\mathrm{M}=\mathrm{Ag}$ or $\mathrm{Au})$ bonds that is followed by the reduction of a cation $\mathrm{M}^{+}$in the cluster to $\mathrm{M}^{0}$, to form $\mathrm{M}_{n}{ }^{0}$ via the formation of NPs. The plausibility of $\mathrm{M}^{+}-\mathrm{M}^{+}$ formation is reviewed. Studies that suggest a revised mechanism for the formation of AgNPs and AuNPs are also reviewed.
\end{abstract}

Keywords: nanoparticles; silver nanoparticles; gold nanoparticles; DFT; standard reduction potentials

\section{Introduction}

Nanoparticles (NP) constitute a special class in chemistry that is situated between molecules and crystals. As such, they possess unique properties that open new scientific horizons. Indeed, the physical [1,2], biological [3,4], and chemical [5,6] characteristics of gold and silver nanoparticles (AuNPs and AgNPs, respectively) confer on them wide applicability [7] in medicine [8-21], agriculture [22-26], photonics [12,18,20,27-30], microelectronics [31-33], and catalysis [30,34-39]. The plasmonic properties of Au and Ag thus stimulate a wide range of research in nanoscale optics, photonics and sensors [40]. Owing to the varied and unique properties exhibited by NPs, nanoparticle research is interdisciplinary, involving scientists from the fields of chemistry, biology, engineering, biotechnology, and material sciences.

The synthesis of metallic nanoparticles in general, and specifically the production of gold and silver nanoparticles, is very simple experimentally. Accordingly, numerous methods have been developed to derive these nanoparticles that exploit their unique properties [7,41-47]. The subject of fruitful, ongoing research [7,45], the different NP production methods are based on chemical, physical, and biological approaches, and can be classified as top-down or bottom-up [48] according to the initial reactants. To control the morphology, particle size, and structure of the produced NPs, template methods [49,50] that employ soft or hard templates are used in a process that also influences the NPs' unique physical and chemical properties. Recently, a novel physical procedure for the production of $\mathrm{Au}$ quantum dots at room temperature was reported by Li et al. [51]. Other physical 
methods, such as photoreduction, are used to synthesize these NPs [52-54]. This review focuses on bottom-up methods, wherein the synthesis comprises nucleation and growth steps. In contrast to the wealth of experimental research on nanoparticle production, scant attention has been given to the study of its mechanisms. When considering bottom-up methods, the metallic ions are often assumed to be reduced to generate metallic atoms, and the aggregation of this is thought to form the nanoparticles. This key assumption, however, is often found to be in contradiction with the standard reduction potentials.

From 2000 to 2020, according to SciFinder, of the 852,987 papers that were published on NPs, $23 \%$ (197,080 papers) were on Au or Ag NPs. Though density-functional theory (DFT) is an important tool for the study of any process mechanism at the molecular level, only 2562 of these papers (1.3\% of the publications on AuNPs or AgNPs) used DFT calculations, a number that represents only about $0.3 \%$ of all publications on NPs (Figure 1). Molecular dynamics is used only after the nascent NPs are formed to calculate their growth to their final size and shape [55-61]. In addition to original research, about 51,000 reviews of the work on NPs were published, of which 6612 (13\%) were also on AuNPs or AgNPs, but only 41 of these include DFT calculations (Figure 2). Insofar as DFT calculations are the most common method to theoretically explore a process, the limited number of publications that exploited DFT indicates that the theoretical study of the production of AgNPs and AuNPs has received limited attention.
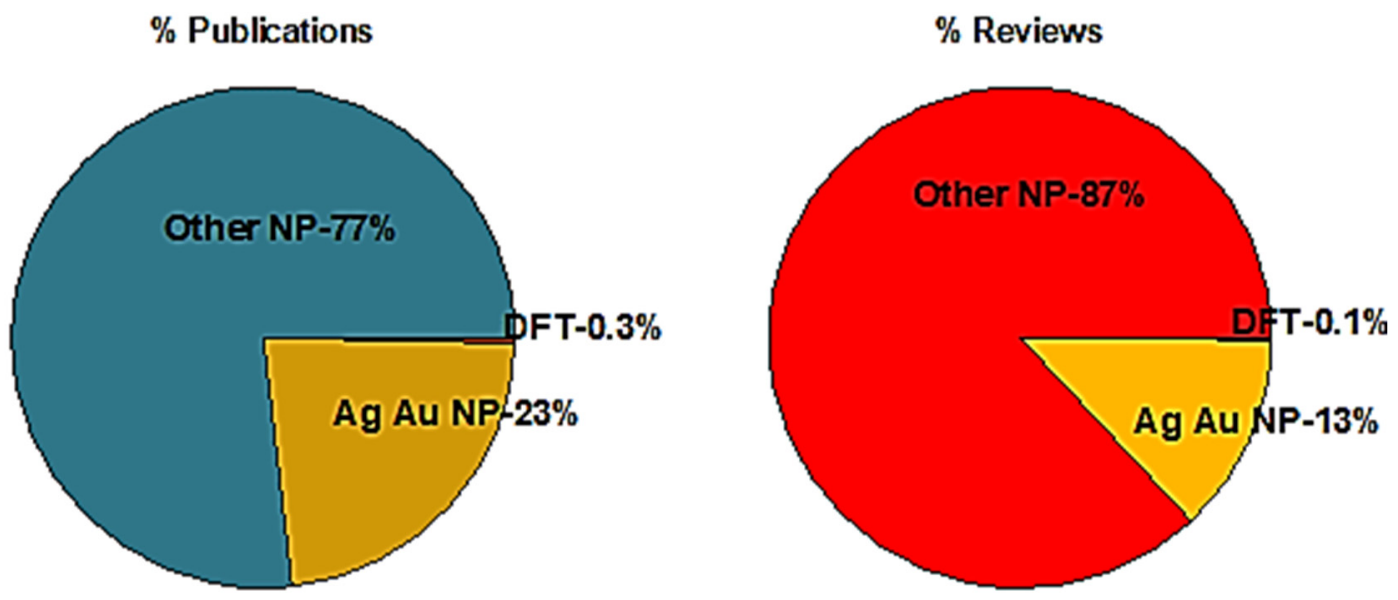

Figure 1. Percentages of publications by subject, 2000-2020, according to SciFinder.
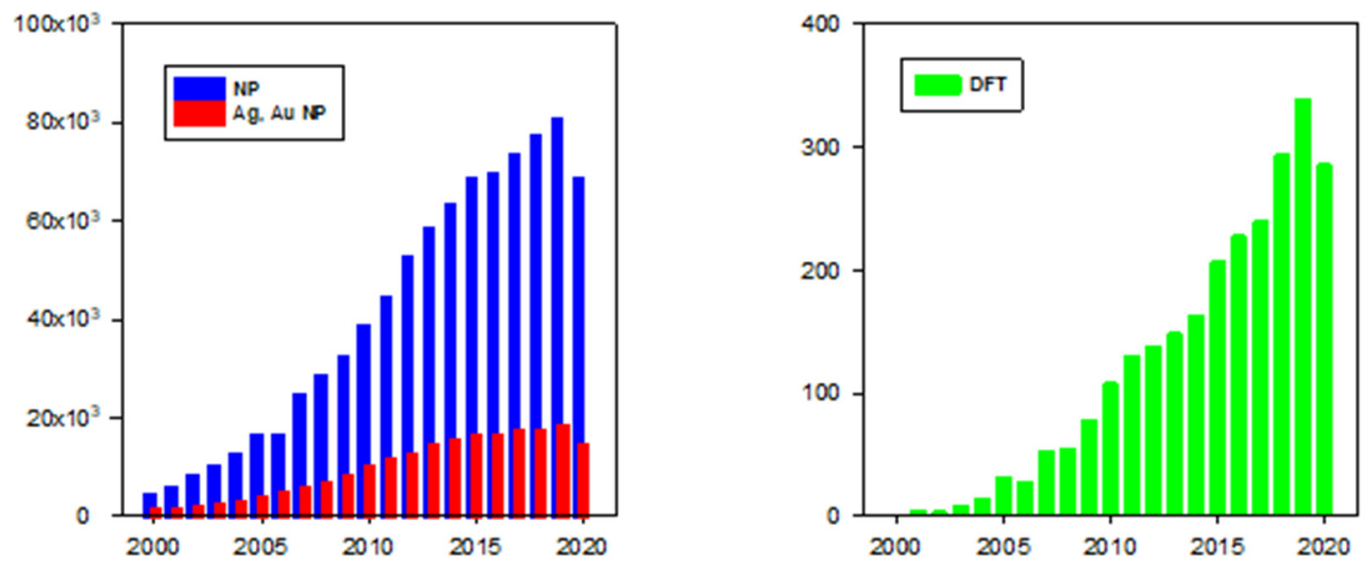

Figure 2. Number of publications in years 2000-2020, results according to SciFinder.

Only a few publications refer to the reduction mechanism of the metallic cations and the formation of nascent NPs, and they emphasize the role of either the stabilization agent (solvent or another reactant) [62-68] or the capping agent [69,70]. Pilay et al. studied the 
nucleation mechanism of AgNPs and AuNPs on a rutile surface, with the role of vacancies studied by calculating adsorption energies [71]. The interaction between $\mathrm{Au}_{9}$ and $\mathrm{Ag}_{9}(\mathrm{a}$ cluster of nine atoms) with pentanal in DMSO was calculated by Saldías et al. [67], while Tamuly et al. [72] calculated the reduction of $\mathrm{Ag}^{+}$using pedicellamide, describing the nucleation and growth process of AgNPs. Though many publications refer to the reduction of $\mathrm{Au}^{\mathrm{III}} \rightarrow \mathrm{Au}^{\mathrm{I}}[66,69,73]$, Barngrover et al. demonstrated the reduction mechanism of $\mathrm{Au}^{\mathrm{III}} \rightarrow \mathrm{Au}^{\mathrm{I}} \rightarrow \mathrm{Au}^{0}$ [64]. While Graham et al. [74] noted the role of ion-ion aggregation, the formation of dimers of $\mathrm{AuX}_{2}{ }^{-}$are essential in the mechanism suggested by Barngrover et al. [64]. In addition, Hudgens et al. [75] demonstrated agglomeration prior to reduction. Regarding Brust-Schiffrin synthesis [76], the early accepted assumption about this method by Schaaff et al. [77] has been that polymeric $\mathrm{Au}^{\mathrm{I}}$ thiolate [Au $\left.{ }^{\mathrm{I}} \mathrm{SR}\right] \mathrm{n}$ can be generated as intermediate precursors [77-81]. Precursor species of these reactions have been identified by Zhu et al. [82]. In this review, we summarize the generally assumed mechanism of the production of nascent AgNPs and AuNPs (the nucleation step) in a bottom-up process-from a single ion to a NP-and the suggested revised mechanism. As we refer only to the early first steps, which proceed from aqueous ions to small metallic clusters that aggregate to form nanoparticles, the review does not refer to NP morphology or shape.

\section{Production of AgNPs and AuNPs-Assumed Mechanism}

The formation of NPs in a bottom-up procedure is assumed to be comprised of the following steps:

$\mathrm{M}^{\mathrm{n}} \mathrm{L}_{\mathrm{m}}+$ reducing agent $\rightarrow \mathrm{M}^{0}$ atom $+\mathrm{mL}+$ oxidized reducing agent

$$
\mathrm{kM}^{0}{ }_{\text {atom }} \rightarrow \mathrm{M}_{\mathrm{k}}{ }^{0} \rightarrow \rightarrow \mathrm{M}^{0}-\mathrm{NP}
$$

In numerous examples in the literature, the metallic ions are assumed to be reduced to give metallic atoms that subsequently aggregate to form the nanoparticles; a few such examples are described below.

Auradha et al. [83] showed that the first step of gold nanoparticle production is the reduction of the gold ions to the zero-valent metal and then the agglomeration of the atoms to form nanoparticles enveloped by stabilizing biomolecules (Figure 3b). For silver nanoparticle production, Lee and Jun [43] showed that the process begins with the reduction of $\mathrm{Ag}^{+}$to $\mathrm{Ag}^{0}$ atoms (Figure 3a). Based on the equation of De Freitas et al. [41], the reduction of $\mathrm{AuCl}_{4}{ }^{-}$using citrate in an aqueous solution, 


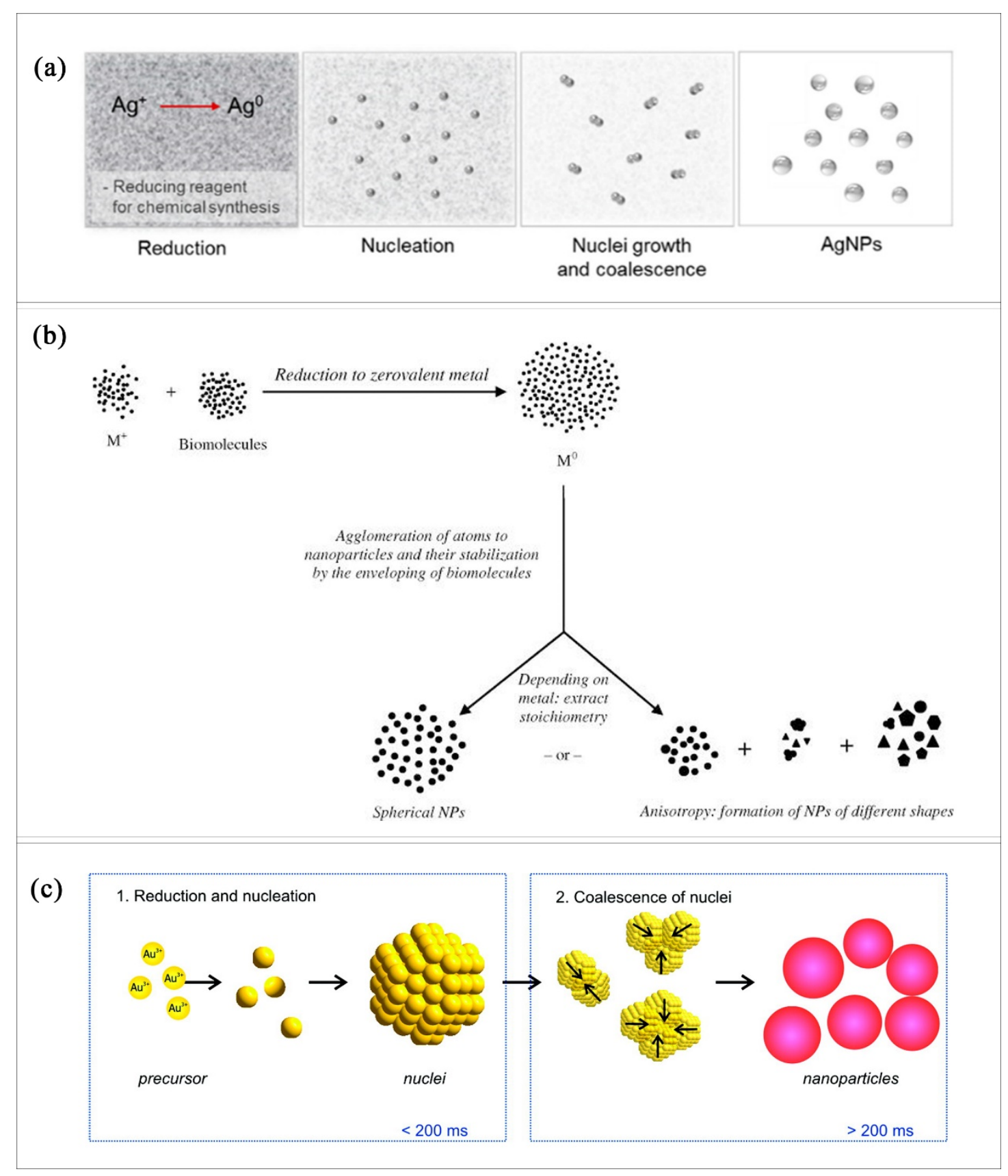

Figure 3. Chemical production of NPs: (a) chemical synthesis method. Reprint of Figure 1C [43]. (b) Mechanism of Gold-NP formation. Reprinted with permission from [83]. Copyright 2015 Elsevier. (c) Schematic illustration for the deduced process of gold nanoparticle formation. Reprinted with permission from [84]. Copyright 2010 ACS publication.

$$
6 \mathrm{AuCl}_{4}{ }^{-}+\mathrm{C}_{6} \mathrm{H}_{8} \mathrm{O}_{7}+5 \mathrm{H}_{2} \mathrm{O} \rightarrow 6 \mathrm{CO}_{2}+24 \mathrm{Cl}^{-}+6 \mathrm{Au}^{0}+18 \mathrm{H}^{+}
$$

is one of the most common ways to synthesize gold nanoparticles. Pastoriza-Santos and Liz-Marzan [85] proposed that the reduction of silver ions to silver nanoparticles by N,Ndimethylformamide (DMF) in water takes place as follows:

$$
\mathrm{HCONMe}_{2}+2 \mathrm{Ag}^{+}+\mathrm{H}_{2} \mathrm{O} \rightleftharpoons 2 \mathrm{Ag}^{0}+\mathrm{Me}_{2} \mathrm{NCOOH}+2 \mathrm{H}^{+}
$$

Polte et al. [84] showed (Figure 3c) that the first step of the synthesis of AuNPs is the reduction of $\mathrm{Au}^{\mathrm{III}}$ to atoms and the aggregation of those atoms followed by the coalescence of the nuclei to form AuNPs. The reduction of $\mathrm{Au}^{\mathrm{III}}$ to form $\mathrm{Au}^{0}$ is also suggested by 
Onesto et al. [86]. The formation of AgNPs was described by Zavras et al. [87] via the reduction of $\mathrm{AgBH}_{4}$ to $\mathrm{Ag}$.

Chen et al. [88] even cited the known standard reduction potential in the production of AuNPs:

$$
\begin{gathered}
\mathrm{AuCl}_{4}^{-}+2 \mathrm{e}^{-} \rightarrow \mathrm{AuCl}_{2}^{-}+2 \mathrm{Cl}^{-} \mathrm{E}^{0}=0.926 \mathrm{~V} \\
\mathrm{AuCl}_{2}{ }^{-}+\mathrm{e}^{-} \rightarrow \mathrm{Au}^{0}+2 \mathrm{Cl}^{-} \mathrm{E}^{0}=1.154 \mathrm{~V}
\end{gathered}
$$

The positive reduction potentials of $\mathrm{Au}$ III and $\mathrm{Au}^{\mathrm{I}}$ given above, and of $\mathrm{Ag}^{+} / \mathrm{Ag}^{\mathrm{I}}$ (0.799 V [89]), have convinced the scientific community that the first step in AuNP or AgNP formation is simply a reduction process that produces hydrated gold or silver atoms, respectively. A positive potential is required to obtain a spontaneous reaction. The positive reduction potentials given for the metallic ions are the potentials of a half reaction (reduction). Insofar as they are positive, for any common reducing agent that has a moderate non-positive reduction potential, the standard potential of the redox reactionwhich comprises a reduction half-reaction and an oxidation half-reaction-will be positive and the reduction will be spontaneous. This is the case when the reduced metal is deposited on a solid surface, e.g., coating a metallic layer or an electrode, as in electroless deposition, wherein the obtained metal is in the solid state. Below are some examples of how metallic silver and gold are produced by using $\mathrm{H}_{2}(\mathrm{~g}), \mathrm{CO}(\mathrm{g})$ or $\mathrm{BH}_{4}{ }^{-}(\mathrm{aq})$ as a reduction agent (the standard reduction potentials of $\mathrm{CO}(\mathrm{g})$ and $\mathrm{BH}_{4}{ }^{-}(\mathrm{aq})$ are from reference [90]). The cell potential, $\left(\mathrm{E}^{0}{ }_{\text {cell }}\right)$, is the sum of $\mathrm{E}^{0}{ }_{\text {red }}$, the reduction potential of the half-reaction, and $\mathrm{E}^{0}{ }_{\mathrm{ox}}$ the oxidation potential of another half-reaction:

Reduction of $\mathrm{Ag}_{(\mathrm{aq})}{ }^{+}$:

$\mathrm{H}_{2(\mathrm{~g})}$ as a reducing agent:

$$
\begin{gathered}
\mathrm{Ag}_{(\mathrm{aq})}^{+}+\mathrm{e}^{-} \leftrightarrows \mathrm{Ag}_{(\mathrm{s})}^{0} \quad \mathrm{E}_{\mathrm{red}}^{0}=0.80 \mathrm{~V} \\
\frac{1}{2} \mathrm{H}_{2(\mathrm{~g})} \leftrightarrows \mathrm{H}_{(\mathrm{aq})}^{+}+\mathrm{e}^{-} \quad \mathrm{E}_{\mathrm{ox}}^{0}=0.00 \mathrm{~V} \\
\mathrm{Ag}_{(\mathrm{aq})}^{+}+\frac{1}{2} \mathrm{H}_{2(\mathrm{~g})} \leftrightarrows \mathrm{H}_{(\mathrm{aq})}^{+}+\mathrm{Ag}_{(\mathrm{s})}^{0} \quad \mathrm{E}_{\mathrm{cell}}^{0}=0.80 \mathrm{~V}
\end{gathered}
$$

$\mathrm{CO}_{(\mathrm{g})}$ as a reducing agent:

$$
\begin{gathered}
2 \mathrm{Ag}_{(\mathrm{aq})}^{+}+2 \mathrm{e}^{-} \leftrightarrows 2 \mathrm{Ag}_{(\mathrm{s})}^{0} \quad \mathrm{E}_{\mathrm{red}}^{0}=0.80 \mathrm{~V} \\
\mathrm{H}_{2} \mathrm{O}_{(\mathrm{l})}+\mathrm{CO}_{(\mathrm{g})} \leftrightarrows \mathrm{CO}_{2(\mathrm{~g})}+2 \mathrm{H}_{(\mathrm{aq})}^{+}+2 \mathrm{e}^{-} \quad \mathrm{E}_{\mathrm{ox}}^{0}=0.10 \mathrm{~V} \\
2 \mathrm{Ag}_{(\mathrm{aq})}^{+}+\mathrm{H}_{2} \mathrm{O}_{(\mathrm{l})}+\mathrm{CO}_{(\mathrm{g})} \leftrightarrows \mathrm{CO}_{2(\mathrm{~g})}+2 \mathrm{H}_{(\mathrm{aq})}^{+}+2 \mathrm{Ag}_{(\mathrm{s})}^{0} \quad \mathrm{E}_{\mathrm{cell}}^{0}=0.90 \mathrm{~V} \\
\mathrm{BH}_{4(\mathrm{aq})}{ }^{-} \text {as a reducing agent: }
\end{gathered}
$$

$$
\begin{gathered}
4 \mathrm{Ag}_{(\mathrm{aq})}^{+}+4 \mathrm{e}^{-} \leftrightarrows 4 \mathrm{Ag}_{(\mathrm{s})}^{0} \quad \mathrm{E}_{\mathrm{red}}^{0}=0.80 \mathrm{~V} \\
4 \mathrm{OH}_{(\mathrm{aq})}^{-}+\mathrm{BH}_{4(\mathrm{aq})}^{-} \leftrightarrows \mathrm{B}(\mathrm{OH})_{4(\mathrm{aq})}^{-}+2 \mathrm{H}_{2(\mathrm{aq})}+4 \mathrm{e}^{-} \quad \mathrm{E}_{\mathrm{ox}}^{0}=1.24 \mathrm{~V} \\
4 \mathrm{Ag}_{(\mathrm{aq})}^{+}+4 \mathrm{OH}_{(\mathrm{aq})}^{-}+\mathrm{BH}_{4(\mathrm{aq})}^{-} \leftrightarrows \mathrm{B}(\mathrm{OH})_{4(\mathrm{aq})}^{-}+2 \mathrm{H}_{2(\mathrm{~g})}+4 \mathrm{Ag}_{(\mathrm{s})}^{0} \quad \mathrm{E}_{\mathrm{cell}}^{0}=2.04 \mathrm{~V}
\end{gathered}
$$

Reduction of $\mathrm{Au}_{(\mathrm{aq})}{ }^{+}$:

$\mathrm{H}_{2(\mathrm{~g})}$ as a reducing agent:

$$
\begin{aligned}
& \mathrm{Ag}_{(\mathrm{aq})}^{+}+\mathrm{e}^{-} \leftrightarrows \mathrm{Ag}_{(\mathrm{s})}^{0} \quad \mathrm{E}_{\mathrm{red}}^{0}=0.80 \mathrm{~V} \\
& \frac{1}{2} \mathrm{H}_{2(\mathrm{~g})} \leftrightarrows \mathrm{H}_{(\mathrm{aq})}^{+}+\mathrm{e}^{-} \quad \mathrm{E}_{\mathrm{ox}}^{0}=0.00 \mathrm{~V}
\end{aligned}
$$




$$
\begin{aligned}
& 2 \mathrm{AuCl}_{2(\mathrm{aq})}^{+}+\frac{1}{2} \mathrm{H}_{2(\mathrm{~g})} \leftrightarrows \mathrm{H}_{(\mathrm{aq})}^{+}+\mathrm{Au}_{(\mathrm{s})}^{0}+2 \mathrm{Cl}_{(\mathrm{aq})}^{-} \quad \mathrm{E}_{\mathrm{cell}}^{0}=1.15 \mathrm{~V} \\
& \mathrm{CO}_{(\mathrm{g})} \text { as a reducing agent: } \\
& 2 \mathrm{AuCl}_{2(\mathrm{aq})}^{+}+2 \mathrm{e}^{-} \leftrightarrows 2 \mathrm{Au}_{(\mathrm{s})}^{0}+4 \mathrm{Cl}_{(\mathrm{aq})}^{-} \quad \mathrm{E}_{\text {red }}^{0}=1.15 \mathrm{~V} \\
& \mathrm{H}_{2} \mathrm{O}_{(\mathrm{l})}+\mathrm{CO}_{(\mathrm{g})} \leftrightarrows \mathrm{CO}_{2(\mathrm{~g})}+2 \mathrm{H}_{(\mathrm{aq})}^{+}+2 \mathrm{e}^{-} \quad \mathrm{E}_{\mathrm{ox}}^{0}=0.10 \mathrm{~V} \\
& 2 \mathrm{AuCl}_{2(\mathrm{aq})}^{+}+\mathrm{H}_{2} \mathrm{O}_{(\mathrm{l})}+\mathrm{CO}_{(\mathrm{g})} \leftrightarrows \mathrm{CO}_{2(\mathrm{~g})}+2 \mathrm{H}_{(\mathrm{aq})}^{+}+\mathrm{Au}_{(\mathrm{s})}^{0}+2 \mathrm{Cl}_{(\mathrm{aq})}^{-} \quad \mathrm{E}_{\mathrm{cell}}^{0}=1.25 \mathrm{~V} \\
& \mathrm{BH}_{4(\mathrm{aq})} \text { - as a reducing agent: } \\
& 4 \mathrm{AuCl}_{2(\mathrm{aq})}^{+}+4 \mathrm{e}^{-} \leftrightarrows 4 \mathrm{Au}_{(\mathrm{s})}^{0}+8 \mathrm{Cl}_{(\mathrm{aq})}^{-} \quad \mathrm{E}_{\mathrm{red}}^{0}=1.15 \mathrm{~V} \\
& 4 \mathrm{OH}_{(\mathrm{aq})}^{-}+\mathrm{BH}_{4(\mathrm{aq})}^{-} \leftrightarrows \mathrm{B}(\mathrm{OH})_{4(\mathrm{aq})}^{-}+2 \mathrm{H}_{2(\mathrm{aq})}+4 \mathrm{e}^{-} \quad \mathrm{E}_{\mathrm{ox}}^{0}=1.24 \mathrm{~V} \\
& 4 \mathrm{AuCl}_{2(\mathrm{aq})}^{+}+4 \mathrm{OH}_{(\mathrm{aq})}^{-}+\mathrm{BH}_{4(\mathrm{aq})}^{-} \leftrightarrows \mathrm{B}(\mathrm{OH})_{4(\mathrm{aq})}^{-}+2 \mathrm{H}_{2(\mathrm{~g})}+4 \mathrm{Au}_{(\mathrm{s})}^{0}+8 \mathrm{Cl}_{(\mathrm{aq})}^{-} \quad \mathrm{E}_{\mathrm{cell}}^{0}=2.39 \mathrm{~V}
\end{aligned}
$$

\section{Standard Reduction Potentials}

As a matter of fact, the positive reduction potentials of $\mathrm{Au}^{\mathrm{III}}, \mathrm{Au}^{\mathrm{I}}$ and $\mathrm{Ag}^{+}$are the standard reduction potentials of the couples $\mathrm{M}^{\mathrm{n}+}$ aq $/ \mathrm{M}^{0}$ solid, while the standard reduction potentials of the relevant couples $\mathrm{M}^{\mathrm{n}+}{ }_{\text {aq }} / \mathrm{M}^{0}$ aq are different, as the solid metal should be evaporated to form hydrated atoms, a process in which energy should be invested. The calculation of $\mathrm{E}^{0}\left(\mathrm{M}^{\mathrm{n}+}{ }_{\mathrm{aq}} / \mathrm{M}^{0}{ }_{\text {aq }}\right)$ follows the equation:

$$
\mathrm{E}^{0}\left(\mathrm{M}^{\mathrm{n}+}{ }_{\text {aq }} / \mathrm{M}^{0}{ }_{\mathrm{aq}}\right)=\mathrm{E}^{0}\left(\mathrm{M}^{\mathrm{n}+}{ }_{\mathrm{aq}} / \mathrm{M}^{0}{ }_{\text {solid }}\right)-\left(\Delta \mathrm{G}^{0} \text { evaporation } / \mathrm{nF}\right)
$$

Reference [91] ( $n$-number of electrons involved in the redox reaction, $\mathrm{F}$ - faraday constant).

The value of $\mathrm{E}^{0}\left(\mathrm{M}^{\mathrm{n}+}{ }_{\text {aq }} / \mathrm{M}^{0}{ }_{\mathrm{aq}}\right)$ is significantly lower than that of $\mathrm{E}^{0}\left(\mathrm{M}^{\mathrm{n}+}{ }_{\text {aq }} / \mathrm{M}^{0}{ }_{\text {solid }}\right)$. Henglein's group [92,93] was the first to calculate the value of the standard reduction potential of silver: $\mathrm{E}^{0}\left(\mathrm{Ag}_{\mathrm{aq}}{ }^{+} / \mathrm{Ag}^{0} \mathrm{aq}\right)=-1.8 \mathrm{~V}$ versus standard hydrogen electrode (SHE). While Henglein's calculation used enthalpies, Mondal et al. [91] recalculated this value using free energy values to obtain $-1.74 \mathrm{~V}$ versus SHE. The standard reduction potential for gold is: $\mathrm{E}^{0}\left(\mathrm{AuCl}_{2}{ }^{-}{ }_{(\mathrm{aq})} / \mathrm{Au}^{0}{ }_{\mathrm{aq}}+2 \mathrm{Cl}^{-}{ }_{(\mathrm{aq})}\right)=-2.23 \mathrm{~V}$ versus $\mathrm{SHE}$ [91]. Negative standard reduction potentials for $\mathrm{E}^{0}\left(\mathrm{M}^{\mathrm{n}+}{ }_{\mathrm{aq}} / \mathrm{M}^{0}{ }_{\text {aq }}\right)$ were also calculated for several typical metals [91]. Table 1 summarizes the values that are given by Mondal et al. [91] relative to those of $\mathrm{E}^{0}\left(\mathrm{M}^{\mathrm{n}+}{ }_{\text {aq }} / \mathrm{M}^{0}{ }_{\text {solid }}\right)$ [89]. The low values of $\mathrm{E}^{0}\left(\mathrm{M}^{\mathrm{n}+}{ }_{\mathrm{aq}} / \mathrm{M}^{0}{ }_{\mathrm{aq}}\right)$ in this table indicate that it is impossible to obtain solvated zero-valent atoms in an aqueous solution, wherein only reduction to a metallic solid is possible. According to these standard reduction potentials, the production of nanoparticles of these metals, e.g., AuNPs and AgNPs, using common moderate reduction agents that do not have significantly high negative reduction standard potentials-e.g., hydrogen [94-96], carbon monoxide [97,98], citrate [95,99-101], hydroxylamine [95], formaldehyde [95], ascorbate [95], squartic acid [95], and $\mathrm{BH}_{4}{ }^{-}$[102-112]cannot start with the simple reduction of the cations to atoms, as commonly assumed. Hafez et al. [113] experimentally confirmed the absence of such cathodic reduction behaviors in a neutral system. The release of single hydrated aqueous atoms of silver or gold without any stabilizing agent by using $\mathrm{H}_{2}(\mathrm{~g}), \mathrm{CO}(\mathrm{g})$ or $\mathrm{BH}_{4}{ }^{-}(\mathrm{aq})$, as in the above example, is thermodynamically impossible, as the potential of the cell becomes negative. 
Table 1. Standard reduction potentials versus SHE; data from references [89,91].

\begin{tabular}{|c|c|c|c|}
\hline Metal & Redox Couple & $\begin{array}{c}\mathrm{E}^{0}\left(\mathbf{M}^{\mathrm{n}+} /\right) \\
\left(\mathbf{M}^{0}{ }_{\text {solid }}\right) \\
\text { V vs. SHE [89] }\end{array}$ & $\begin{array}{c}\mathrm{E}^{0}\left(\mathbf{M}^{\mathrm{n}+} /\right) \\
\left(\mathrm{M}^{0}{ }_{\text {aq }}\right) \mathrm{V} \text { vs. SHE [91] }\end{array}$ \\
\hline Zinc & $\mathrm{Zn}^{2+}{ }_{(\mathrm{aq})} / \mathrm{Zn}^{0}$ & -0.76 & -1.25 \\
\hline Cadmium & $\mathrm{Cd}^{2+}{ }_{(\mathrm{aq})} / \mathrm{Cd}^{0}$ & -0.4 & -0.8 \\
\hline Mercury & $\mathrm{Hg}^{2+}{ }_{(\mathrm{aq})} / \mathrm{Hg}^{0}$ & $+0.85^{\mathrm{a}}$ & 0.68 \\
\hline Copper & $\mathrm{Cu}_{(\mathrm{aq})}^{+} / \mathrm{Cu}^{0}$ & 0.52 & -2.57 \\
\hline Silver & $\mathrm{Ag}_{(\mathrm{aq})}^{+} / \mathrm{Ag}^{0}$ & 0.8 & -1.74 \\
\hline Gold & $\mathrm{AuCl}_{2}{ }^{-}{ }_{(\mathrm{aq})} / \mathrm{Au}^{0}+2 \mathrm{Cl}^{-}{ }_{(\mathrm{aq})}$ & 1.15 [114] & -2.23 \\
\hline Nickel & $\mathrm{Ni}^{2+}{ }_{(\mathrm{aq})} / \mathrm{Ni}^{0}$ & -0.25 & -2.24 \\
\hline Palladium & $\mathrm{Pd}^{2+}{ }_{(\mathrm{aq})} / \mathrm{Pd}^{0}$ & 0.95 & -0.81 \\
\hline Platinum & $\mathrm{Pt}^{2+}{ }_{(\mathrm{aq})} / \mathrm{Pt}^{0}$ & 1.18 & -1.51 \\
\hline Cobalt & $\mathrm{Co}^{2+}{ }_{(\mathrm{aq})} / \mathrm{Co}^{0}$ & -0.28 & -2.25 \\
\hline Rhodium & $\mathrm{RhCl}_{6}{ }^{3-}{ }_{(\mathrm{aq})} /\left(\mathrm{Rh}^{0}+6 \mathrm{Cl}^{-}{ }_{\text {(aq) }}\right)$ & +0.43 & -1.33 \\
\hline Iridium & $\mathrm{IrCl}_{6}{ }^{2-}{ }_{(\mathrm{aq})} /\left(\mathrm{Ir}^{0}+6 \mathrm{Cl}^{-}{ }_{(\mathrm{aq})}\right)$ & +0.77 & -0.83 \\
\hline Iron & $\mathrm{Fe}^{2+}{ }_{(\mathrm{aq})} / \mathrm{Fe}^{0}$ & -0.44 & -2.36 \\
\hline Ruthenium & $\mathrm{RuCl}_{3(\mathrm{aq})} /\left(\mathrm{Ru}^{0}+3 \mathrm{Cl}^{-}{ }_{(\mathrm{aq})}\right)$ & $0.51[115]$ & -1.55 \\
\hline Osmium & $\left(\mathrm{OsO}_{4(\mathrm{aq})}+8 \mathrm{H}^{+}{ }_{(\mathrm{aq})}\right) /\left(\mathrm{Os}^{0}+4 \mathrm{H}_{2} \mathrm{O}\right)$ & +0.84 & -0.12 \\
\hline Manganese & $\mathrm{Mn}^{2+}{ }_{(\mathrm{aq})} / \mathrm{Mn}^{0}$ & -1.19 & -2.43 \\
\hline Chromium & $\mathrm{Cr}^{3+}{ }_{(\mathrm{aq})} / \mathrm{Cr}^{0}$ & -0.74 & -1.95 \\
\hline Vanadium & $\mathrm{V}^{2+}{ }_{(\mathrm{aq})} / \mathrm{V}^{0}$ & -1.17 & -5.08 \\
\hline Titanium & $\mathrm{Ti}^{3+}{ }_{(\mathrm{aq})} / \mathrm{Ti}^{0}$ & -1.37 & -3.17 \\
\hline
\end{tabular}

Reduction of $\mathrm{Ag}_{(\mathrm{aq})}{ }^{+}$:

$\mathrm{H}_{2(\mathrm{~g})}$ as a reducing agent:

$$
\begin{gathered}
\mathrm{Ag}_{(\mathrm{aq})}^{+}+\mathrm{e}^{-} \leftrightarrows \mathrm{Ag}_{(\mathrm{aq})}^{0} \quad \mathrm{E}_{\mathrm{red}}^{0}=-1.74 \mathrm{~V} \\
\frac{1}{2} \mathrm{H}_{2(\mathrm{~g})} \leftrightarrows \mathrm{H}_{(\mathrm{aq})}^{+}+\mathrm{e}^{-} \quad \mathrm{E}_{\mathrm{ox}}^{0}=0.00 \mathrm{~V} \\
\mathrm{Ag}_{(\mathrm{aq})}^{+}+\frac{1}{2} \mathrm{H}_{2(\mathrm{~g})} \leftrightarrows \mathrm{H}_{(\mathrm{aq})}^{+}+\mathrm{Ag}_{(\mathrm{aq})}^{0} \quad \mathrm{E}_{\mathrm{cell}}^{0}=-1.74 \mathrm{~V}
\end{gathered}
$$

$\mathrm{CO}_{(\mathrm{g})}$ as a reducing agent:

$$
\begin{gathered}
2 \mathrm{Ag}_{(\mathrm{aq})}^{+}+2 \mathrm{e}^{-} \leftrightarrows 2 \mathrm{Ag}_{(\mathrm{aq})}^{0} \quad \mathrm{E}_{\mathrm{red}}^{0}=-1.74 \mathrm{~V} \\
\mathrm{H}_{2} \mathrm{O}_{(\mathrm{l})}+\mathrm{CO}_{(\mathrm{g})} \leftrightarrows \mathrm{CO}_{2(\mathrm{~g})}+2 \mathrm{H}_{(\mathrm{aq})}^{+}+2 \mathrm{e}^{-} \quad \mathrm{E}_{\mathrm{ox}}^{0}=0.10 \mathrm{~V} \\
2 \mathrm{Ag}_{(\mathrm{aq})}^{+}+\mathrm{H}_{2} \mathrm{O}_{(\mathrm{l})}+\mathrm{CO}_{(\mathrm{g})} \leftrightarrows \mathrm{CO}_{2(\mathrm{~g})}+2 \mathrm{H}_{(\mathrm{aq})}^{+}+2 \mathrm{Ag}_{(\mathrm{aq})}^{0} \quad \mathrm{E}_{\text {cell }}^{0}=-1.64 \mathrm{~V}
\end{gathered}
$$

$\mathrm{BH}_{4(\mathrm{aq})}{ }^{-}$as a reducing agent:

$$
\begin{gathered}
4 \mathrm{Ag}_{(\mathrm{aq})}^{+}+4 \mathrm{e}^{-} \leftrightarrows 4 \mathrm{Ag}_{(\mathrm{aq})}^{0} \quad \mathrm{E}_{\mathrm{red}}^{0}=-1.74 \mathrm{~V} \\
4 \mathrm{OH}_{(\mathrm{aq})}^{-}+\mathrm{BH}_{4(\mathrm{aq})}^{-} \leftrightarrows \mathrm{B}(\mathrm{OH})_{4(\mathrm{aq})}^{-}+2 \mathrm{H}_{2(\mathrm{aq})}+4 \mathrm{e}^{-} \quad \mathrm{E}_{\mathrm{ox}}^{0}=1.24 \mathrm{~V} \\
4 \mathrm{Ag}_{(\mathrm{aq})}^{+}+4 \mathrm{OH}_{(\mathrm{aq})}^{-}+\mathrm{BH}_{4(\mathrm{aq})}^{-} \leftrightarrows \mathrm{B}(\mathrm{OH})_{4(\mathrm{aq})}^{-}+2 \mathrm{H}_{2(\mathrm{~g})}+4 \mathrm{Ag}_{(\mathrm{aq})}^{0} \quad \mathrm{E}_{\text {cell }}^{0}=-0.50 \mathrm{~V}
\end{gathered}
$$

Reduction of $\mathrm{Au}_{(\mathrm{aq})}{ }^{+}$:

$\mathrm{H}_{2(\mathrm{~g})}$ as a reducing agent:

$$
\mathrm{AuCl}_{2(\mathrm{aq})}^{+}+\mathrm{e}^{-} \leftrightarrows \mathrm{Au}_{(\mathrm{aq})}^{0}+2 \mathrm{Cl}_{(\mathrm{aq})}^{-} \quad \mathrm{E}_{\mathrm{red}}^{0}=-2.23 \mathrm{~V}
$$




$$
\begin{aligned}
& \frac{1}{2} \mathrm{H}_{2(\mathrm{~g})} \leftrightarrows \mathrm{H}_{(\mathrm{aq})}^{+}+\mathrm{e}^{-} \quad \mathrm{E}_{\mathrm{ox}}^{0}=0.00 \mathrm{~V} \\
& 2 \mathrm{AuCl}_{2(\mathrm{aq})}^{+}+\frac{1}{2} \mathrm{H}_{2(\mathrm{~g})} \leftrightarrows \mathrm{H}_{(\mathrm{aq})}^{+}+\mathrm{Au}_{(\mathrm{aq})}^{0}+2 \mathrm{Cl}_{(\mathrm{aq})}^{-} \quad \mathrm{E}_{\mathrm{cell}}^{0}=-2.23 \mathrm{~V} \\
& 2 \mathrm{AuCl}_{2(\mathrm{aq})}^{+}+2 \mathrm{e}^{-} \leftrightarrows 2 \mathrm{Au}_{(\mathrm{aq})}^{0}+4 \mathrm{Cl}_{(\mathrm{aq})}^{-} \quad \mathrm{E}_{\mathrm{red}}^{0}=-2.23 \mathrm{~V} \\
& \mathrm{H}_{2} \mathrm{O}_{(\mathrm{l})}+\mathrm{CO}_{(\mathrm{g})} \leftrightarrows \mathrm{CO}_{2(\mathrm{~g})}+2 \mathrm{H}_{(\mathrm{aq})}^{+}+2 \mathrm{e}^{-} \quad \mathrm{E}_{\mathrm{ox}}^{0}=0.10 \mathrm{~V} \\
& 2 \mathrm{AuCl}_{2(\mathrm{aq})}^{+}+\mathrm{H}_{2} \mathrm{O}_{(\mathrm{l})}+\mathrm{CO}_{(\mathrm{g})} \leftrightarrows \mathrm{CO}_{2(\mathrm{~g})}+2 \mathrm{H}_{(\mathrm{aq})}^{+}+2 \mathrm{Au}_{(\mathrm{aq})}^{0}+4 \mathrm{Cl}_{(\mathrm{aq})}^{-} \quad \mathrm{E}_{\mathrm{cell}}^{0}=-2.13 \mathrm{~V} \\
& \mathrm{BH}_{4(\mathrm{aq})} \text { - as a reducing agent: } \\
& 4 \mathrm{AuCl}_{2(\mathrm{aq})}^{+}+4 \mathrm{e}^{-} \leftrightarrows 4 \mathrm{Au}_{(\mathrm{aq})}^{0}+8 \mathrm{Cl}_{(\mathrm{aq})}^{-} \quad \mathrm{E}_{\mathrm{red}}^{0}=-2.23 \mathrm{~V} \\
& 4 \mathrm{OH}_{(\mathrm{aq})}^{-}+\mathrm{BH}_{4(\mathrm{aq})}^{-} \leftrightarrows \mathrm{B}(\mathrm{OH})_{4(\mathrm{aq})}^{-}+2 \mathrm{H}_{2(\mathrm{aq})}+4 \mathrm{e}^{-} \quad \mathrm{E}_{\mathrm{ox}}^{0}=1.24 \mathrm{~V} \\
& 4 \mathrm{AuCl}_{2(\mathrm{aq})}^{+}+4 \mathrm{OH}_{(\mathrm{aq})}^{-}+\mathrm{BH}_{4(\mathrm{aq})}^{-} \leftrightarrows \mathrm{B}(\mathrm{OH})_{4(\mathrm{aq})}^{-}+2 \mathrm{H}_{2(\mathrm{~g})}+4 \mathrm{Au}_{(\mathrm{aq})}^{0}+8 \mathrm{Cl}_{(\mathrm{aq})}^{-} \quad \mathrm{E}_{\mathrm{cell}}^{0}=-0.99 \mathrm{~V}
\end{aligned}
$$

\section{Formation of $M-M \quad M-M^{I}$ and $M^{I}-M^{I}$ Bonds}

The standard reduction potential $\mathrm{E}^{0}\left(\mathrm{M}^{\mathrm{n}+} /\left(\mathrm{M}^{0}{ }_{\mathrm{aq}}\right)\right.$ is significantly lower than the values of $\mathrm{E}^{0}\left(\mathrm{M}^{\mathrm{n}+} /\left(\mathrm{M}^{0}{ }_{\text {solid }}\right)\right.$ for all of the metals, and these values are negative for many common metallic ions. Therefore, the assumption-that metallic ions undergo reduction to metallic atoms that aggregate to form the nanoparticles-did not hold for almost all of the common reducing agents. Recent DFT calculations [91,116,117] revealed that the mechanism of metallic nanoparticle formation, especially of AuNPs and AgNPs, consists of several steps that begin with the formation of agglomerates with $M^{\mathrm{I}}-\mathrm{M}^{\mathrm{I}}(\mathrm{M}=\mathrm{Ag}$ or $\mathrm{Au})$ bonds and $\mathrm{M}^{0}-\mathrm{M}^{\mathrm{I}}$ bonds that are eventually reduced to form $\mathrm{Ag}_{\mathrm{n}}{ }^{0}$ or $\mathrm{Au}_{\mathrm{n}}{ }^{0}$ as the intermediate to AgNPs or AuNPs. Silver and gold atoms are known, respectively, to form Ag-Ag [118,119] and $\mathrm{Au}-\mathrm{Au}[75,120-125]$ bonds and form clusters. Bond formation is also known to occur between silver atoms and silver ions [92,119,126-128], between silver ions [129-131], and between gold ions [80,120,131,132]. Henglein et al. [92,119,127] experimentally studied the formation of small silver clusters and small clusters in which silver ions were involved. Jin et al. [120] emphasized the importance of protecting organic ligands, especially thiolate, when attempting to obtain such clusters [124]. The role of thiolate was also studied by Barngrover et al. [62], while Polte et al. [84] demonstrated the role of stabilizing agents. Zhu et al. [80] and Wu et al. [133] found that the formation of the Au' ${ }^{\mathrm{I} S R}$ intermediate is critical to obtain $\mathrm{Au}_{25}$ nanoclusters of high purity and in large yields. Loh et al. [132] used ab initio calculations on gold nucleation to suggest that strong gold-gold atom coupling and water-mediated metastable gold complexes are involved in the nucleation of nanocrystals in aqueous solutions. Understanding the intermediate steps in nuclei formation has important implications for the formation and growth of both crystalline and amorphous materials. Zavras et al. [87] used DFT calculations to show that $\left[\mathrm{Ag}_{3}(\mathrm{H})_{2}-x\left(\mathrm{BH}_{4}\right)_{\mathrm{x}} \mathrm{L}_{\mathrm{n}}\right]^{+}$clusters provide a direct link between mixed hydride/borohydride silver clusters $(x=1)$, dihydride silver clusters $(x=0)$ and silver clusters. In DFT-based research, Barngrover et al. [64] showed how $\mathrm{Au}^{0}$-containing species can be formed without assuming the formation of $\mathrm{Au}^{0}$ atoms (radical species), using methanol and benzene solvents as models for one-phase and two-phase gold nanoparticle growth processes, the precursors of the AuNP were $\mathrm{AuCl}_{2}{ }^{-}$, $\mathrm{AuBr}_{2}{ }^{-}, \mathrm{AuI}_{2}{ }^{-}, \mathrm{AuClPH}_{3}$, and $\mathrm{AuCl}(\mathrm{H}) \mathrm{SCH}_{3}{ }^{(-)}$that initially form $\mathrm{Au}^{0}$ clusters: $\mathrm{Au}_{2} \mathrm{X}_{2}{ }^{2-}$ $\left(\mathrm{X}=\mathrm{Cl}^{-}, \mathrm{Br}^{-}, \mathrm{I}^{-}\right)$and then $\mathrm{Au}_{3} \mathrm{Cl}_{3}{ }^{2-}$. Larger clusters are formed by reactions between these clusters or between such clusters and additional $\mathrm{AuCl}_{2}{ }^{-}$species [64]. 


\section{Formation of AgNPs and AuNPs-A New Approach}

Since the simple reduction of $\mathrm{Ag}^{+}(\mathrm{aq})$ or $\mathrm{Au}^{+}(\mathrm{aq})$ to form a hydrated $\mathrm{Ag}^{0}$ aq or $\mathrm{Au}^{0}{ }_{\mathrm{aq}}$ atom, respectively, is not possible with most reduction agents, a new approach entailing a multi-step reaction was proposed $[91,116,117]$. The initial step in this approach, prior to the reduction, is the formation of clusters in which $\mathrm{Ag}^{+}-\mathrm{Ag}^{+}$or $\mathrm{Au}^{+}-\mathrm{Au}^{+}$bonds are involved via the formation of the NPs.

The complexity of AgNP and AuNP formation was demonstrated experimentally [91,117]. In these studies, the precursor of the AgNPs or AuNPs was an aqueous solution of $\mathrm{Ag}\left(\mathrm{H}_{2} \mathrm{O}\right)_{2}{ }^{+}$or $\mathrm{AuCl}_{2}{ }^{-}$, and aqueous $\mathrm{BH}_{4}{ }^{-}$was used as a reduction agent. Spectroscopic results obtained by using a stop-flow method clearly show that the reduction of $\mathrm{Ag}\left(\mathrm{H}_{2} \mathrm{O}\right)_{2}{ }^{+}$ or $\mathrm{AuCl}_{2}{ }^{-}$to form AgNPs or AuNPs, respectively, is a multi-step reaction. At least four [91] or three [117] assembly and disassembly processes were observed in a very short interval of time prior to the formation of AgNPs or AuNPs, respectively.

DFT calculations have shown that $\mathrm{Ag}\left(\mathrm{H}_{2} \mathrm{O}\right) \mathrm{H}$ is the first intermediate that is formed in the process of AgNP production from $\mathrm{Ag}\left(\mathrm{H}_{2} \mathrm{O}\right)_{2}{ }^{+}$using $\mathrm{H}_{2}$ [116] or $\mathrm{BH}_{4}{ }^{-}$[91] in aqueous solutions. AgNPs are formed via the reaction of $\mathrm{Ag}\left(\mathrm{H}_{2} \mathrm{O}\right) \mathrm{H}$ with another silver ion and oligomerization followed by the release of $\mathrm{H}_{2}$. The first step of this process is [116]:

$\mathrm{Ag}\left(\mathrm{H}_{2} \mathrm{O}\right) \mathrm{H}+\mathrm{Ag}\left(\mathrm{H}_{2} \mathrm{O}\right)_{2}{ }^{+} \rightarrow \mathrm{Ag}_{2}\left(\mathrm{H}_{2} \mathrm{O}\right)_{3} \mathrm{H}^{+} \Delta \mathrm{G}^{0}=-19.38 \mathrm{kcal} / \mathrm{mol}\left(\Delta \mathrm{G}^{\#}=2.46 \mathrm{kcal} / \mathrm{mol}\right)$

After oligomerization, the release of $\mathrm{H}_{2}$ and the reduction of $\mathrm{Ag}^{+}$to $\mathrm{Ag}^{0}$ is thermodynamically possible, e.g.:

$$
\left(\mathrm{Ag}\left(\mathrm{H}_{2} \mathrm{O}\right) \mathrm{H}\right)_{2} \mathrm{Ag}^{+} \rightarrow\left(\mathrm{Ag}\left(\mathrm{H}_{2} \mathrm{O}\right)_{2} \mathrm{Ag}^{+}+\mathrm{H}_{2} \Delta \mathrm{G}^{0}=-1.99 \mathrm{kcal} / \mathrm{mol}\right.
$$

When $\mathrm{BH}_{4}{ }^{-}$(aq) was used as the reducing agent, the formation of $\mathrm{Ag}\left(\mathrm{H}_{2} \mathrm{O}\right) \mathrm{H}$ was just a side reaction, because the silver cations mainly catalyze the hydrolysis of $\mathrm{BH}_{4}{ }^{-}$. This explains why the Creighton process [134] $\left(\mathrm{BH}_{4}{ }^{-}\right.$is used as the reducing agent) requires such a large excess of $\mathrm{BH}_{4}{ }^{-}$to reduce the silver cations.

In contrast to these results, the starting point for the formation of AuNPs [117] using the Creighton process [134] is $\mathrm{AuH}_{2}{ }^{-}$, as the production of $\mathrm{Au}\left(\mathrm{H}_{2} \mathrm{O}\right) \mathrm{H}$ is unfavored thermodynamically [117]. $\mathrm{Au}^{3+}$ is reduced by $\mathrm{BH}_{4}{ }^{-}$to $\mathrm{Au}^{+}$in a very exothermic reaction, and this reduction is followed by some oligomerization steps. The spontaneous release of $\mathrm{H}_{2}$ is the starting point in the reduction of $\mathrm{Au}^{+}$to $\mathrm{Au}^{0}$ via the formation of AuNPs [117]:

$$
\mathrm{Au}_{6} \mathrm{H}_{8}{ }^{2-} \rightarrow \mathrm{Au}_{6} \mathrm{H}_{6}{ }^{2-}+\mathrm{H}_{2} \Delta G^{0}=-0.96 \mathrm{kcal} / \mathrm{mol}
$$

In the $\mathrm{Au}$ system, when $\mathrm{BH}_{4}{ }^{-}(\mathrm{aq})$ is used as a reduction agent (Creighton procedure [134]), the reduction of the central cation is the main process [117]. In the silver system, in contrast, the $\mathrm{Ag}^{+}$ions mainly catalyze the $\mathrm{BH}_{4-}$ hydrolysis, and the reduction of the central cation is only a side process. In both procedures, $\mathrm{BH}_{4}{ }^{-}$ions ligate the central metal cation to form $\mathrm{Ag}\left(\mathrm{H}_{2} \mathrm{O}\right) \mathrm{BH}_{4}$ or $\mathrm{AuCl}\left(\mathrm{BH}_{4}\right)^{-}$and $\mathrm{Ag}\left(\mathrm{BH}_{4}\right)_{2}{ }^{-}$or $\mathrm{Au}\left(\mathrm{BH}_{4}\right)_{2}{ }^{-}$. But while the silver ion hydrolysis of these species forms several $\mathrm{Ag}\left(\mathrm{H}_{2} \mathrm{O}\right)\left(\mathrm{BH}_{4-\mathrm{n}} \mathrm{OH}_{\mathrm{n}}\right)^{-}$, $n=1-3$ and $\mathrm{Ag}\left(\mathrm{BH}_{4-\mathrm{n}} \mathrm{OH}_{\mathrm{n}}\right)\left(\mathrm{BH}_{4-\mathrm{n}^{\prime}} \mathrm{OH}_{\mathrm{n}^{\prime}}\right)^{-}, n=1-3$ and $n^{\prime}=1-3$ intermediates [91], the hydrolysis of the $\mathrm{BH}_{4}{ }^{-}$ligands in the gold system only forms $\mathrm{BH}_{3} \mathrm{OH}^{-}$ligands, and further hydrolysis of the ligands results in the loss of the $\mathrm{BH}(\mathrm{OH})_{2}$ intermediate and the formation of the hydrides $\mathrm{AuClH}^{-}$and $\mathrm{AuH}_{2}{ }^{-}$[117]. The $\Delta \mathrm{G}^{0}$ and $\Delta \mathrm{G}^{\#}$ values are very similar in the $\mathrm{Au}^{+}$and $\mathrm{Ag}^{+}$systems for one $\mathrm{BH} 4^{-}$ligand or for two such ligands. A comparison of these values is given in Table 2. 
Table 2. $\Delta \mathrm{G}^{0}$ and $\Delta \mathrm{G}^{\#}$ values for the first hydrolysis of $\mathrm{BH}_{4}{ }^{-}$.

\begin{tabular}{|c|c|c|c|c|}
\hline \multirow{2}{*}{ Reaction } & \multicolumn{2}{|c|}{$\Delta \mathrm{G}^{0}(\mathrm{kcal} / \mathrm{mol})$} & \multicolumn{2}{|c|}{$\Delta \mathrm{G}^{\#}(\mathrm{kcal} / \mathrm{mol})$} \\
\hline & $\mathbf{M}=\mathbf{A g}^{+}[91]$ & $\mathbf{M}=\mathbf{A} \mathbf{u}^{+}[117]$ & $\mathbf{M}=\mathbf{A g}^{+}[91]$ & $\mathbf{M}=\mathbf{A u}^{+}[117]$ \\
\hline $\mathrm{ML}\left(\mathrm{BH}_{4}\right)^{\mathrm{n}}+\mathrm{H}_{2} \mathrm{O} \rightarrow \mathrm{ML}\left(\mathrm{BH}_{3} \mathrm{OH}\right)^{\mathrm{n}}+\mathrm{H}_{2}{ }^{\mathrm{a}}$ & 0.38 & -3.61 & 20.09 & 23.73 \\
\hline $\mathrm{M}\left(\mathrm{BH}_{4}\right)_{2}{ }^{-}+\mathrm{H}_{2} \mathrm{O} \rightarrow \mathrm{M}\left(\mathrm{BH}_{4}\right)\left(\mathrm{BH}_{3} \mathrm{OH}\right)^{-}+\mathrm{H}_{2}$ & -0.05 & -3.01 & 19.88 & 22.16 \\
\hline $\mathrm{M}\left(\mathrm{BH}_{4}\right)\left(\mathrm{BH}_{3} \mathrm{OH}\right)^{-}+\mathrm{H}_{2} \mathrm{O} \rightarrow \mathrm{M}\left(\mathrm{BH}_{4}\right)_{2}{ }^{-}+\mathrm{H}_{2}$ & 0.09 & -3.00 & 19.72 & 20.39 \\
\hline
\end{tabular}

${ }^{\mathrm{a}}$ For $\mathrm{M}=\mathrm{Ag}^{+} \mathrm{L}=\mathrm{H}_{2} \mathrm{O}$ and $n=0$, for $\mathrm{M}=\mathrm{Au}^{+} \mathrm{L}=\mathrm{Cl}^{-}$and $n=-1$.

The $\Delta \mathrm{G}^{\#}$ values are significantly lower than the value for the first hydrolysis of $\mathrm{BH}_{4}{ }^{-}$ in absence of the metallic cations, which catalyze the hydrolysis, even though the $\Delta \mathrm{G}^{0}$ value is quite similar [91]:

$$
\mathrm{BH}_{4}{ }^{-} \text {aq }+\mathrm{H}_{2} \mathrm{O} \rightarrow\left[\mathrm{BH}_{3}(\mathrm{OH})\right]^{-} \text {aq }+\mathrm{H}_{2} \Delta G^{0}=-0.07 \mathrm{kcal} / \mathrm{mol}\left(\Delta G^{\ddagger}=54.78 \mathrm{kcal} / \mathrm{mol}\right)
$$

\section{Conclusions}

Noble Metal NPs can be produced by using a variety of bottom-up and top-down physical, chemical, and biological methods that require the addition of chemical stabilizers and biological materials. In addition, methods have been developed to control the morphology, particle size, and structure of the produced NPs, and thus affect their unique physical and chemical properties.

This review concentrated on the bottom-up methods that do not require a stabilization agent. The standard reduction potentials of $\mathrm{M}^{\mathrm{n}+}{ }_{\text {aq }} / \mathrm{M}^{0}{ }_{\text {aq }}$ differ significantly from those of $\mathrm{M}^{\mathrm{n}+}{ }_{\text {aq }} / \mathrm{M}^{0}$ solid. The values of $\mathrm{E}^{0}\left(\mathrm{M}^{\mathrm{n}+}{ }_{\mathrm{aq}} / \mathrm{M}^{0}{ }_{\mathrm{aq}}\right)$ for many typical metallic cations are negative in contrast to the positive values of $\mathrm{E}^{0}\left(\mathrm{M}^{\mathrm{n}+}{ }_{\mathrm{aq}} / \mathrm{M}^{0}{ }_{\text {solid }}\right)$ exhibited by the same cations. As a result, the assumption that metallic NP production begins with the simple reduction of $\mathrm{M}^{\mathrm{n}+}$ aq is not valid for most reducing agents, and as such, $\mathrm{M}^{0}$ - atoms are not produced. The process of NP formation is more complex and involves many steps.

A novel approach to AuNP and AgNP formation is based on the tendency of $\mathrm{Ag}^{+}$ and $\mathrm{Au}^{+}$to agglomerate and form $\mathrm{M}^{\mathrm{I}}-\mathrm{M}^{\mathrm{I}}, \mathrm{M}^{\mathrm{I}}-\mathrm{M}$ and $\mathrm{M}-\mathrm{M}$ bonds. According to this new approach $[91,116,117]$, the reduction is a multi-step process, the initial step in which is the formation of clusters that involve $\mathrm{Ag}^{+}-\mathrm{Ag}^{+}$or $\mathrm{Au}^{+}-\mathrm{Au}^{+}$bonds prior to the reduction and release of $\mathrm{H}_{2}$ via the formation of the NPs. The potential applicability of this novel approach in the context of the formation of AgNPs, AuNPs, and other metallic NPs warrants its further investigation, both experimentally and theoretically and with other metallic cations and reducing agents.

Author Contributions: B.R.K. and H.K. participated in the writing of the manuscript, and they have all approved of its final version. Both authors have read and agreed to the published version of the manuscript.

Funding: This research received no external funding.

Data Availability Statement: Not applicable.

Acknowledgments: B.R. is thankful to Ariel University for a Ph.D. fellowship.

Conflicts of Interest: The authors declare no conflict of interest.

\section{References}

1. Kiss, F.D.; Miotto, R.; Ferraz, A.C. Size effects on silver nanoparticles' properties. Nanotechnology 2011, 22, 275708. [CrossRef]

2. González, A.L.; Noguez, C.; Beránek, J.; Barnard, A.S. Size, shape, stability, and color of plasmonic silver nanoparticles. J. Phys. Chem. C 2014, 118, 9128-9136. [CrossRef]

3. Li, W.R.; Xie, X.B.; Shi, Q.S.; Zeng, H.Y.; Ou-Yang, Y.S.; Chen, Y. Ben Antibacterial activity and mechanism of silver nanoparticles on Escherichia coli. Appl. Microbiol. Biotechnol. 2010, 85, 1115-1122. [CrossRef] [PubMed]

4. Marambio-Jones, C.; Hoek, E.M.V. A review of the antibacterial effects of silver nanomaterials and potential implications for human health and the environment. J. Nanoparticle Res. 2010, 12, 1531-1551. [CrossRef] 
5. Yaqoob, S.B.; Adnan, R.; Rameez Khan, R.M.; Rashid, M. Gold, Silver, and Palladium Nanoparticles: A Chemical Tool for Biomedical Applications. Front. Chem. 2020, 8, 376. [CrossRef]

6. Amendola, V.; Meneghetti, M.; Stener, M.; Guo, Y.; Chen, S.; Crespo, P.; García, M.A.; Hernando, A.; Pengo, P.; Pasquato, L. Physico-Chemical Characteristics of Gold Nanoparticles. In Comprehensive Analytical Chemistry; Elsevier B.V.: Amsterdam, The Netherlands, 2014; Volume 66, pp. 81-152.

7. Yaqoob, A.A.; Umar, K.; Ibrahim, M.N.M. Silver nanoparticles: Various methods of synthesis, size affecting factors and their potential applications-A review. Appl. Nanosci. 2020, 10, 1369-1378. [CrossRef]

8. Moyano, D.F.; Rotello, V.M. Nano meets biology: Structure and function at the nanoparticle interface. Langmuir 2011, 27, 10376-10385. [CrossRef]

9. Mokammel, M.A.; Islam, M.J.; Hasanuzzaman, M.; Hashmi, S. Nanoscale Materials for Self-Cleaning and Antibacterial Applications. In Reference Module in Materials Science and Materials Engineering; Elsevier: Amsterdam, The Netherlands, 2019.

10. Penninckx, S.; Heuskin, A.-C.; Michiels, C.; Lucas, S. Gold Nanoparticles as a Potent Radiosensitizer: A Transdisciplinary Approach from Physics to Patient. Cancers 2020, 12, 2021. [CrossRef] [PubMed]

11. Panzarini, E.; Mariano, S.; Carata, E.; Mura, F.; Rossi, M.; Dini, L. Intracellular Transport of Silver and Gold Nanoparticles and Biological Responses: An Update. Int. J. Mol. Sci. 2018, 19, 1305. [CrossRef]

12. Kim, J.H.; Shin, D.H.; Lee, H.S.; Jang, C.W.; Kim, J.M.; Seo, S.W.; Kim, S.; Choi, S.H. Enhancement of efficiency in graphene/porous silicon solar cells by co-doping graphene with gold nanoparticles and bis(trifluoromethanesulfonyl)-amide. J. Mater. Chem. C 2017, 5, 9005-9011. [CrossRef]

13. Huang, X.; Jain, P.K.; El-Sayed, I.H.; El-Sayed, M.A. Plasmonic photothermal therapy (PPTT) using gold nanoparticles. Lasers Med. Sci. 2008, 23, 217-228. [CrossRef] [PubMed]

14. Singh, P.; Kim, Y.J.; Wang, C.; Mathiyalagan, R.; Yang, D.C. The development of a green approach for the biosynthesis of silver and gold nanoparticles by using Panax ginseng root extract, and their biological applications. Artif. Cells Nanomed. Biotechnol. 2015, 44, 1-8. [CrossRef]

15. Singh, P.; Singh, H.; Kim, Y.J.; Mathiyalagan, R.; Wang, C.; Yang, D.C. Extracellular synthesis of silver and gold nanoparticles by Sporosarcina koreensis DC4 and their biological applications. Enzym. Microb. Technol. 2016, 86, 75-83. [CrossRef]

16. Soshnikova, V.; Kim, Y.J.; Singh, P.; Huo, Y.; Markus, J.; Ahn, S.; Castro-Aceituno, V.; Kang, J.; Chokkalingam, M.; Mathiyalagan, R.; et al. Cardamom fruits as a green resource for facile synthesis of gold and silver nanoparticles and their biological applications. Artif. Cells Nanomed. Biotechnol. 2018, 46, 108-117. [CrossRef] [PubMed]

17. Hussain, I.; Singh, N.B.; Singh, A.; Singh, H.; Singh, S.C. Green synthesis of nanoparticles and its potential application. Biotechnol. Lett. 2016, 38, 545-560. [CrossRef]

18. Xu, S.; Ouyang, W.; Xie, P.; Lin, Y.; Qiu, B.; Lin, Z.; Chen, G.; Guo, L. Highly Uniform Gold Nanobipyramids for Ultrasensitive Colorimetric Detection of Influenza Virus. Anal. Chem. 2017, 89, 1617-1623. [CrossRef] [PubMed]

19. Kailasa, S.K.; Koduru, J.R.; Desai, M.L.; Park, T.J.; Singhal, R.K.; Basu, H. Recent progress on surface chemistry of plasmonic metal nanoparticles for colorimetric assay of drugs in pharmaceutical and biological samples. TrAC Trends Anal. Chem. 2018, 105, 106-120. [CrossRef]

20. Reznickova, A.; Novotna, Z.; Kvitek, O.; Kolska, Z.; Svorcik, V. Gold, silver and carbon nanoparticles grafted on activated polymers for biomedical applications. J. Nanosci. Nanotechnol. 2015, 15, 10053-10073. [CrossRef] [PubMed]

21. Khodashenas, B.; Ardjmand, M.; Baei, M.S.; Rad, A.S.; Akbarzadeh, A. Conjugation of pectin biopolymer with Au-nanoparticles as a drug delivery system: Experimental and DFT studies. Appl. Organomet. Chem. 2020, 34. [CrossRef]

22. Banerjee, P.; Satapathy, M.; Mukhopahayay, A.; Das, P. Leaf extract mediated green synthesis of silver nanoparticles from widely available Indian plants: Synthesis, characterization, antimicrobial property and toxicity analysis. Bioresour. Bioprocess. 2014, 1, 3 [CrossRef]

23. Panda, M.K.; Singh, Y.D.; Behera, R.K.; Dhal, N.K. Biosynthesis of Nanoparticles and Their Potential Application in Food and Agricultural Sector. In Green Nanoparticles. Nanotechnology in the Life Sciences; Springer: Cham, Switzerland, 2020 ; pp. $213-225$.

24. Greulich, C.; Braun, D.; Peetsch, A.; Diendorf, J.; Siebers, B.; Epple, M.; Köller, M. The toxic effect of silver ions and silver nanoparticles towards bacteria and human cells occurs in the same concentration range. RSC Adv. 2012, 2, 6981-6987. [CrossRef]

25. Vijayaraghavan, K.; Ashokkumar, T. Plant-mediated biosynthesis of metallic nanoparticles: A review of literature, factors affecting synthesis, characterization techniques and applications. J. Environ. Chem. Eng. 2017, 5, 4866-4883. [CrossRef]

26. Kashyap, P.L.; Kumar, S.; Srivastava, A.K.; Sharma, A.K. Myconanotechnology in agriculture: A perspective. World J. Microbiol. Biotechnol. 2013, 29, 191-207. [CrossRef] [PubMed]

27. Ramanujam, N.R.; Wilson, K.S.J. Optical properties of silver nanocomposites and photonic band gap-Pressure dependence. Opt. Commun. 2016, 368, 174-179. [CrossRef]

28. Venditti, I. Gold Nanoparticles in Photonic Crystals Applications: A Review. Materials 2017, 10, 97. [CrossRef] [PubMed]

29. Zhao, W.; Wang, S.; Liu, B.; Verzhbitskiy, I.; Li, S.; Giustiniano, F.; Kozawa, D.; Loh, K.P.; Matsuda, K.; Okamoto, K.; et al. Exciton-Plasmon Coupling and Electromagnetically Induced Transparency in Monolayer Semiconductors Hybridized with Ag Nanoparticles. Adv. Mater. 2016, 28, 2709-2715. [CrossRef]

30. Feng, L.; Gao, G.; Huang, P.; Wang, K.; Wang, X.; Luo, T.; Zhang, C. Optical properties and catalytic activity of bimetallic gold-silver nanoparticles. Nano Biomed. Eng. 2010, 2, 258-267. [CrossRef] 
31. Teranishi, T. Fabrication and electronic properties of gold nanoparticle superlattices. Comptes Rendus Chim. 2003, 6, 979-987. [CrossRef]

32. Peng, P.; Hu, A.; Gerlich, A.P.; Zou, G.; Liu, L.; Zhou, Y.N. Joining of Silver Nanomaterials at Low Temperatures: Processes, Properties, and Applications. ACS Appl. Mater. Interfaces 2015, 7, 12597-12618. [CrossRef] [PubMed]

33. Naik, G.V.; Shalaev, V.M.; Boltasseva, A. Alternative plasmonic materials: Beyond gold and silver. Adv. Mater. 2013, 25, 3264-3294. [CrossRef]

34. Jin, R.; Zeng, C.; Zhou, M.; Chen, Y. Atomically Precise Colloidal Metal Nanoclusters and Nanoparticles: Fundamentals and Opportunities. Chem. Rev. 2016, 116, 10346-10413. [CrossRef] [PubMed]

35. Mohammadi, P.; Daneshafruz, H.; Sheibani, H. Gold nanoparticles on cyanuric citric acid functionalized magnetic SBA-16 as an effective catalyst for dye reduction. Phys. E Low-Dimens. Syst. Nanostructures 2021, 126, 114392. [CrossRef]

36. Lee, Y.J.; Cha, S.-H.; Kim, H.; Choi, S.E.; Cho, S.; Park, Y. Diallyl disulphide-loaded spherical gold nanoparticles and acorn-like silver nanoparticles synthesised using onion extract: Catalytic activity and cytotoxicity. Artif. Cells Nanomed. Biotechnol. 2020, 48, 948-960. [CrossRef]

37. Ye, Y.; Yang, H.; Zhang, H.; Jiang, J. A promising $\mathrm{Ag}_{2} \mathrm{CrO}_{4} / \mathrm{LaFeO}_{3}$ heterojunction photocatalyst applied to photo-Fenton degradation of RhB. Environ. Technol. 2020, 41, 1486-1503. [CrossRef] [PubMed]

38. Singh, J.; Dhaliwal, A.S. Plasmon-induced photocatalytic degradation of methylene blue dye using biosynthesized silver nanoparticles as photocatalyst. Environ. Technol. 2020, 41, 1520-1534. [CrossRef]

39. Sudheeshkumar, V.; Sulaiman, K.O.; Scott, R.W.J. Activation of atom-precise clusters for catalysis. Nanoscale Adv. 2020, 2, 55-69. [CrossRef]

40. Khurana, K.; Jaggi, N. Localized Surface Plasmonic Properties of Au and Ag Nanoparticles for Sensors: A Review. Plasmonics 2021, 1, 3.

41. Freitas de Freitas, L.; Varca, G.; dos Santos Batista, J.; Benévolo Lugão, A. An Overview of the Synthesis of Gold Nanoparticles Using Radiation Technologies. Nanomaterials 2018, 8, 939. [CrossRef]

42. Lee, K.X.; Shameli, K.; Yew, Y.P.; Teow, S.-Y.; Jahangirian, H.; Rafiee-Moghaddam, R.; Webster, T. Recent Developments in the Facile Bio-Synthesis of Gold Nanoparticles (AuNPs) and Their Biomedical Applications. Int. J. Nanomed. 2020, 15, 275-300. [CrossRef] [PubMed]

43. Lee, S.; Jun, B.-H. Silver Nanoparticles: Synthesis and Application for Nanomedicine. Int. J. Mol. Sci. 2019, 20, 865. [CrossRef] [PubMed]

44. Beyene, H.D.; Werkneh, A.A.; Bezabh, H.K.; Ambaye, T.G. Synthesis paradigm and applications of silver nanoparticles (AgNPs), a review. Sustain. Mater. Technol. 2017, 13, 18-23. [CrossRef]

45. Syafiuddin, A.; Salim, M.R.; Beng Hong Kueh, A.; Hadibarata, T.; Nur, H. A Review of Silver Nanoparticles: Research Trends, Global Consumption, Synthesis, Properties, and Future Challenges. J. Chin. Chem. Soc. 2017, 64, 732-756. [CrossRef]

46. Daruich De Souza, C.; Ribeiro Nogueira, B.; Rostelato, M.E.C.M. Review of the methodologies used in the synthesis gold nanoparticles by chemical reduction. J. Alloys Compd. 2019, 798, 714-740. [CrossRef]

47. Zhao, P.; Li, N.; Astruc, D. State of the art in gold nanoparticle synthesis. Coord. Chem. Rev. 2013, 257, 638-665. [CrossRef]

48. Iqbal, P.; Preece, J.A.; Mendes, P.M. Nanotechnology: The "Top-Down" and "Bottom-Up" Approaches. In Supramolecular Chemistry; John Wiley \& Sons, Ltd.: Chichester, UK, 2012.

49. Xie, Y.; Kocaefe, D.; Chen, C.; Kocaefe, Y. Review of Research on Template Methods in Preparation of Nanomaterials. J. Nanomater. 2016, 2016, 2302595. [CrossRef]

50. Doustkhah, E.; Rostamnia, S.; Tsunoji, N.; Henzie, J.; Takei, T.; Yamauchi, Y.; Ide, Y. Templated synthesis of atomically-thin Ag nanocrystal catalysts in the interstitial space of a layered silicate. Chem. Commun. 2018, 54, 4402-4405. [CrossRef] [PubMed]

51. Shirsath, S.E.; Liu, X.; Assadi, M.H.N.; Younis, A.; Yasukawa, Y.; Karan, S.K.; Zhang, J.; Kim, J.; Wang, D.; Morisako, A.; et al. Au quantum dots engineered room temperature crystallization and magnetic anisotropy in $\mathrm{CoFe}_{2} \mathrm{O}_{4}$ thin films. Nanoscale Horiz. 2019, 4, 516-525. [CrossRef] [PubMed]

52. Hu, H.; Wu, X.; Wang, H.; Wang, H.; Zhou, J. Photo-reduction of Ag nanoparticles by using cellulose-based micelles as soft templates: Catalytic and antimicrobial activities. Carbohydr. Polym. 2019, 213, 419-427. [CrossRef] [PubMed]

53. Lee, H.E.; Ahn, H.Y.; Mun, J.; Lee, Y.Y.; Kim, M.; Cho, N.H.; Chang, K.; Kim, W.S.; Rho, J.; Nam, K.T. Amino-acid- A nd peptide-directed synthesis of chiral plasmonic gold nanoparticles. Nature 2018, 556, 360-364. [CrossRef] [PubMed]

54. Hashimoto, S.; Werner, D.; Uwada, T. Studies on the interaction of pulsed lasers with plasmonic gold nanoparticles toward light manipulation, heat management, and nanofabrication. J. Photochem. Photobiol. C Photochem. Rev. 2012, 13, 28-54. [CrossRef]

55. Gutenberg Open Science: Understanding Shape Control in Gold Nanoparticles from Molecular Dynamics Simulations. Available online: https:/ / openscience.ub.uni-mainz.de/handle/20.500.12030/4558 (accessed on 15 March 2021).

56. Jiang, S.; Zhang, Y.; Gan, Y.; Chen, Z.; Peng, H. Molecular dynamics study of neck growth in laser sintering of hollow silver nanoparticles with different heating rates. J. Phys. D Appl. Phys. 2013, 46, 335302. [CrossRef]

57. Zeng, Q.; Jiang, X.; Yu, A.; Lu, G. Growth mechanisms of silver nanoparticles: A molecular dynamics study. Nanotechnology 2007, 18, 035708. [CrossRef]

58. Meena, S.K.; Sulpizi, M. Understanding the microscopic origin of gold nanoparticle anisotropic growth from molecular dynamics simulations. Langmuir 2013, 29, 14954-14961. [CrossRef] 
59. Yang, P.; Zeng, Q.; Dong, K.; Zhu, H. A quick method for developing interparticle force models of spherical gold nanoparticles from molecular dynamics simulation. Powder Technol. 2020, 362, 501-506. [CrossRef]

60. Kaminski, M.; Jurkiewicz, K.; Burian, A.; Brodka, A. The structure of gold nanoparticles: Molecular dynamics modeling and its verification by X-ray diffraction. J. Appl. Crystallogr. 2020, 53, 1-8. [CrossRef]

61. Pan, H.; Ko, S.H.; Grigoropoulos, C.P. The solid-state neck growth mechanisms in low energy laser sintering of gold nanoparticles: A Molecular dynamics simulation study. J. Heat Transf. 2008, 130. [CrossRef]

62. Barngrover, B.M.; Aikens, C.M. The golden pathway to thiolate-stabilized nanoparticles: Following the formation of gold(I) thiolate from gold(III) chloride. J. Am. Chem. Soc. 2012, 134, 12590-12595. [CrossRef]

63. Toroz, D.; Corni, S. Peptide synthesis of gold nanoparticles: The early steps of gold reduction investigated by density functional theory. Nano Lett. 2011, 11, 1313-1318. [CrossRef]

64. Barngrover, B.M.; Manges, T.J.; Aikens, C.M. Prediction of nonradical Au(0)-containing precursors in nanoparticle growth processes. J. Phys. Chem. A 2015, 119, 889-895. [CrossRef]

65. Yoneya, M.; Sugisawa, S.Y. Simulation of Colloidal Silver Nanoparticle Formation from a Precursor Complex. J. Phys. Chem. C 2019, 123, 11257-11263. [CrossRef]

66. Li, Y.; Zaluzhna, O.; Zangmeister, C.D.; Allison, T.C.; Tong, Y.J. Different mechanisms govern the two-phase Brust-Schiffrin dialkylditelluride syntheses of Ag and Au nanoparticles. J. Am. Chem. Soc. 2012, 134, 1990-1992. [CrossRef] [PubMed]

67. Saldías, C.; Leiva, Á.; Bonardd, S.; Quezada, C.; Saldías, S.; Pino, M.; Radic', D. A facile one-step synthesis of noble metal nanoparticles in DMSO using poly(ethylene glycol)-poly(e-caprolactone) block copolymers. React. Funct. Polym. 2015, 96, 78-88. [CrossRef]

68. Zehlike, L.; Peters, A.; Ellerbrock, R.H.; Degenkolb, L.; Klitzke, S. Aggregation of $\mathrm{TiO}_{2}$ and Ag nanoparticles in soil solutionEffects of primary nanoparticle size and dissolved organic matter characteristics. Sci. Total Environ. 2019, 688, 288-298. [CrossRef]

69. Singh, D.K.; Jagannathan, R.; Khandelwal, P.; Abraham, P.M.; Poddar, P. In situ synthesis and surface functionalization of gold nanoparticles with curcumin and their antioxidant properties: An experimental and density functional theory investigation. Nanoscale 2013, 5, 1882-1893. [CrossRef] [PubMed]

70. Valenti, L.E.; Giacomelli, C.E. Stability of silver nanoparticles: Agglomeration and oxidation in biological relevant conditions. J. Nanoparticle Res. 2017, 19, 1-9. [CrossRef]

71. Pillay, D.; Wang, Y.; Hwang, G.S. Nucleation and growth of $1 \mathrm{~B}$ metal clusters on rutile $\mathrm{TiO}_{2}(110)$ : Atomic level understanding from first principles studies. Catal. Today 2005, 105, 78-84. [CrossRef]

72. Tamuly, C.; Hazarika, M.; Bordoloi, M.; Bhattacharyya, P.K.; Kar, R. Biosynthesis of Ag nanoparticles using pedicellamide and its photocatalytic activity: An eco-friendly approach. Spectrochim. Acta Part A Mol. Biomol. Spectrosc. 2014, 132, 687-691. [CrossRef] [PubMed]

73. Ojea-Jiménez, I.; Campanera, J.M. Molecular modeling of the reduction mechanism in the citrate-mediated synthesis of gold nanoparticles. J. Phys. Chem. C 2012, 116, 23682-23691. [CrossRef]

74. Graham, T.R.; Renslow, R.; Govind, N.; Saunders, S.R. Precursor Ion-Ion Aggregation in the Brust-Schiffrin Synthesis of Alkanethiol Nanoparticles. J. Phys. Chem. C 2016, 120, 19837-19847. [CrossRef]

75. Hudgens, J.W.; Pettibone, J.M.; Senftle, T.P.; Bratton, R.N. Reaction mechanism governing formation of 1,3-bis(diphenylphosphino) propane-protected gold nanoclusters. Inorg. Chem. 2011, 50, 10178-10189. [CrossRef]

76. Brust, M.; Walker, M.; Bethell, D.; Schiffrin, D.J.; Whyman, R. Synthesis of thiol-derivatised gold nanoparticles in a two-phase liquid-liquid system. J. Chem. Soc. Chem. Commun. 1994, 801-802. [CrossRef]

77. Schaaff, T.G.; Shafigullin, M.N.; Khoury, J.T.; Vezmar, I.; Whetten, R.L.; Cullen, W.G.; First, P.N.; Gutiérrez-Wing, C.; Ascensio, J.; Jose-Yacamán, M.J. Isolation of smaller nanocrystal Au molecules: Robust quantum effects in optical spectra. J. Phys. Chem. B 1997, 101, 7885-7891. [CrossRef]

78. Briñas, R.P.; Hu, M.; Qian, L.; Lymar, E.S.; Hainfeld, J.F. Gold nanoparticle size controlled by polymeric Au(I) thiolate precursor size. J. Am. Chem. Soc. 2008, 130, 975-982. [CrossRef]

79. Negishi, Y.; Nobusada, K.; Tsukuda, T. Glutathione-protected gold clusters revisited: Bridging the gap between gold(I)-thiolate complexes and thiolate-protected gold nanocrystals. J. Am. Chem. Soc. 2005, 127, 5261-5270. [CrossRef] [PubMed]

80. Zhu, M.; Lanni, E.; Garg, N.; Bier, M.E.; Jin, R. Kinetically controlled, high-yield synthesis of Au25 clusters. J. Am. Chem. Soc. 2008, 130, 1138-1139. [CrossRef]

81. Jin, R. Quantum sized, thiolate-protected gold nanoclusters. Nanoscale 2010, 2, 343-362. [CrossRef]

82. Zhu, L.; Zhang, C.; Guo, C.; Wang, X.; Sun, P.; Zhou, D.; Chen, W.; Xue, G. New insight into intermediate precursors of Brust-Schiffrin gold nanoparticles synthesis. J. Phys. Chem. C 2013, 117, 11399-11404. [CrossRef]

83. Anuradha, J.; Abbasi, T.; Abbasi, S.A. An eco-friendly method of synthesizing gold nanoparticles using an otherwise worthless weed pistia (Pistia stratiotes L.). J. Adv. Res. 2015, 6, 711-720. [CrossRef] [PubMed]

84. Polte, J.; Erler, R.; Thünemann, A.F.; Sokolov, S.; Ahner, T.T.; Rademann, K.; Emmerling, F.; Kraehnert, R. Nucleation and growth of gold nanoparticles studied via in situ small angle X-ray scattering at millisecond time resolution. ACS Nano 2010, 4, $1076-1082$. [CrossRef] [PubMed]

85. Pastoriza-Santos, I.; Liz-Marzán, M. Formation and Stabilization of Silver Nanoparticles through Reduction by N,NDimethylformamide. Langmuir 1999, 15, 948-951. [CrossRef] 
86. Onesto, V.; Gentile, F.; Russo, M.; Villani, M.; Candeloro, P.; Perozziello, G.; Malara, N.; Fabrizio, E.D.; Coluccio, M.L. Kinetic Rate Constants of Gold Nanoparticle Deposition on Silicon. Langmuir 2019, 35, 14258-14265. [CrossRef]

87. Zavras, A.; Ariafard, A.; Khairallah, G.N.; White, J.M.; Mulder, R.J.; Canty, A.J.; O’Hair, R.A.J. Synthesis, structure and gas-phase reactivity of the mixed silver hydride borohydride nanocluster $[\mathrm{Ag} 3(\mu 3-\mathrm{H})(\mu 3-\mathrm{BH} 4) \mathrm{LPh} 3] \mathrm{BF} 4(\mathrm{LPh}=$ bis(diphenylphosphino)methane). Nanoscale 2015, 7, 18129-18137. [CrossRef] [PubMed]

88. Chen, Y.C.; Chen, J.Y.; Wu, W.W. In Situ Observation of Au Nanostructure Evolution in Liquid Cell TEM. J. Phys. Chem. C 2017, 121, 26069-26075. [CrossRef]

89. Lide, D.R. CRC Handbook of Chemistry and Physics, 85th ed.; CRC Press: Boca Raton, FL, USA, 2004.

90. Bratsch, S.G. Standard Electrode Potentials and Temperature Coefficients in Water at 298.15 K. J. Phys. Chem. Ref. Data 1989, 18, 1-21. [CrossRef]

91. Mondal, T.; Sermiagin, A.; Meyerstein, D.; Zidki, T.; Kornweitz, H. On the mechanism of reduction of $\mathrm{M}\left(\mathrm{H}_{2} \mathrm{O}\right)_{\mathrm{m}}{ }^{\mathrm{n}+}$ by borohydride: The case of $\mathrm{Ag}\left(\mathrm{H}_{2} \mathrm{O}\right)_{2}{ }^{+}$. Nanoscale 2020, 12, 1657-1672. [CrossRef]

92. Linnert, T.; Mulvaney, P.; Henglein, A.; Weller, H. Long-Lived Nonmetallic Silver Clusters in Aqueous Solution: Preparation and Photolysis. J. Am. Chem. Soc. 1990, 112, 4657-4664. [CrossRef]

93. Henglein, A. Colloidal Silver Nanoparticles: Photochemical Preparation and Interaction with O2, CCl4, and Some Metal Ions. Chem. Mater. 1998, 10, 444-450. [CrossRef]

94. Halpern, J. Homogeneous catalytic activation of molecular hydrogen by metal ions and complexes. J. Phys. Chem. 1959, 63, 398-403. [CrossRef]

95. Hu, Y.; Zhang, A.Q.; Li, H.J.; Qian, D.J.; Chen, M. Synthesis, Study, and Discrete Dipole Approximation Simulation of Ag-Au Bimetallic Nanostructures. Nanoscale Res. Lett. 2016, 11, 209. [CrossRef]

96. Merga, G.; Wilson, R.; Lynn, G.; Milosavljevic, B.H.; Meisel, D. Redox catalysis on "naked" silver nanoparticles. J. Phys. Chem. C 2007, 111, 12220-12226. [CrossRef]

97. Kopple, K.; Meyerstein, D.; Meisel, D. Mechanism of the catalytic hydrogen production by gold sols. H/D isotope effect studies. J. Phys. Chem. 1980, 84, 870-875. [CrossRef]

98. Huang, H.; Du Toit, H.; Ben-Jaber, S.; Wu, G.; Panariello, L.; Thanh, N.T.K.; Parkin, I.P.; Gavriilidis, A. Rapid synthesis of gold nanoparticles with carbon monoxide in a microfluidic segmented flow system. React. Chem. Eng. 2019, 4, 884-890. [CrossRef]

99. El Badawy, A.M.; Luxton, T.P.; Silva, R.G.; Scheckel, K.G.; Suidan, M.T.; Tolaymat, T.M. Impact of environmental conditions ( $\mathrm{pH}$, ionic strength, and electrolyte type) on the surface charge and aggregation of silver nanoparticles suspensions. Environ. Sci. Technol. 2010, 44, 1260-1266. [CrossRef]

100. Jia, C.J.; Schüth, F. Colloidal metal nanoparticles as a component of designed catalyst. Phys. Chem. Chem. Phys. 2011, 13, 2457-2487. [CrossRef]

101. Evanoff, D.D.; Chumanov, G. Synthesis and optical properties of silver nanoparticles and arrays. ChemPhysChem 2005, 6, 1221-1231. [CrossRef]

102. Hervés, P.; Pérez-Lorenzo, M.; Liz-Marzán, L.M.; Dzubiella, J.; Lub, Y.; Ballauff, M. Catalysis by metallic nanoparticles in aqueous solution: Model reactions. Chem. Soc. Rev. 2012, 41, 5577-5587. [CrossRef] [PubMed]

103. Roucoux, A.; Schulz, J.; Patin, H. Reduced transition metal colloids: A novel family of reusable catalysts? Chem. Rev. 2002, 102, 3757-3778. [CrossRef] [PubMed]

104. Carpenter, E.E. Iron nanoparticles as potential magnetic carriers. J. Magn. Magn. Mater. 2001, 225, 17-20. [CrossRef]

105. Dreaden, E.C.; Alkilany, A.M.; Huang, X.; Murphy, C.J.; El-Sayed, M.A. The golden age: Gold nanoparticles for biomedicine. Chem. Soc. Rev. 2012, 41, 2740-2779. [CrossRef] [PubMed]

106. Lewis, L.N. Chemical Catalysis by Colloids and Clusters. Chem. Rev. 1993, 93, 2693-2730. [CrossRef]

107. Kudaibergenov, S.E.; Tatykhanova, G.S.; Selenova, B.S. Polymer Protected and Gel Immobilized Gold and Silver Nanoparticles in Catalysis. J. Inorg. Organomet. Polym. Mater. 2016, 26, 1198-1211. [CrossRef]

108. Adhikary, J.; Meyerstein, D.; Marks, V.; Meistelman, M.; Gershinsky, G.; Burg, A.; Shamir, D.; Kornweitz, H.; Albo, Y. Sol-gel entrapped $\mathrm{Au}^{0}$ - and $\mathrm{Ag}^{0}$-nanoparticles catalyze reductive de-halogenation of halo-organic compounds by $\mathrm{BH}_{4}{ }^{-}$. Appl. Catal. $\mathrm{B}$ Environ. 2018, 239, 450-462. [CrossRef]

109. Mondal, J.; Kundu, S.K.; Hung Ng, W.K.; Singuru, R.; Borah, P.; Hirao, H.; Zhao, Y.; Bhaumik, A. Fabrication of Ruthenium Nanoparticles in Porous Organic Polymers: Towards Advanced Heterogeneous Catalytic Nanoreactors. Chem. Eur. J. 2015, 21, 19016-19027. [CrossRef] [PubMed]

110. Choi, S.; Jeong, Y.; Yu, J. Spontaneous hydrolysis of borohydride required before its catalytic activation by metal nanoparticles. Catal. Commun. 2016, 84, 80-84. [CrossRef]

111. Solomon, S.D.; Bahadory, M.; Jeyarajasingam, A.V.; Rutkowsky, S.A.; Boritz, C.; Mulfinger, L. Synthesis and study of silver nanoparticles. J. Chem. Educ. 2007, 84, 322-325. [CrossRef]

112. Shahwan, T.; Abu Sirriah, S.; Nairat, M.; Boyaci, E.; Eroĝlu, A.E.; Scott, T.B.; Hallam, K.R. Green synthesis of iron nanoparticles and their application as a Fenton-like catalyst for the degradation of aqueous cationic and anionic dyes. Chem. Eng. J. 2011, 172, 258-266. [CrossRef]

113. Hafez, M.E.; Ma, H.; Peng, Y.Y.; Ma, W.; Long, Y.T. Correlated Anodic-Cathodic Nanocollision Events Reveal Redox Behaviors of Single Silver Nanoparticles. J. Phys. Chem. Lett. 2019, 10, 3276-3281. [CrossRef]

114. Harris, D.C. Quantitative Chemical Analysis; W. H. Freeman: New York, NY, USA, 2007; ISBN 9781319164300. 
115. Povar, I.; Spinu, O. Ruthenium redox equilibria: 3. Pourbaix diagrams for the systems Ru-H2O and Ru-Cl-H2O. J. Electrochem. Sci. Eng. 2016, 6, 145-153. [CrossRef]

116. Kornweitz, H.; Meyerstein, D. Mechanisms of Reduction of $\mathrm{M}\left(\mathrm{H}_{2} \mathrm{O}\right)_{\mathrm{k}}{ }^{\mathrm{n}+}$ to Form $\mathrm{M}^{\circ}$-Nano-Particles in Aqueous Solutions Differs from That Commonly Assumed: The Reduction of $\mathrm{Ag}\left(\mathrm{H}_{2} \mathrm{O}\right)_{2}{ }^{+}$by $\mathrm{H}_{2}$. J. Phys. Chem. C 2018, 122, 25043-25050. [CrossRef]

117. Mondal, T.; Sermiagin, A.; Zidki, T.; Bogot, A.; Meyerstein, D.; Kornweitz, H. On the Differences in the Mechanisms of Reduction of $\mathrm{AuCl}_{2}{ }^{-}$and $\mathrm{Ag}\left(\mathrm{H}_{2} \mathrm{O}\right)_{2}{ }^{+}$with $\mathrm{BH}_{4}{ }^{-}$. J. Phys. Chem. A 2021. [CrossRef]

118. Baetzold, R.C. Silver-Water Clusters: A Computation of Agn $(\mathrm{H} 2 \mathrm{O}) \mathrm{m}$ for $\mathrm{n}=1-6$; $\mathrm{M}=1-8$. J. Phys. Chem. C 2017, 121, 11811-11823. [CrossRef]

119. Henglein, A.; Mulvaney, P.; Linnert, T. Chemistry of Agn aggregates in aqueous solution: Non-metallic oligomeric clusters and metallic particles. Faraday Discuss. 1991, 92, 31-44. [CrossRef]

120. Jin, R.; Zhu, Y.; Qian, H. Quantum-sized gold nanoclusters: Bridging the gap between organometallics and nanocrystals. Chem. Eur. J. 2011, 17, 6584-6593. [CrossRef] [PubMed]

121. Azubel, M.; Koivisto, J.; Malola, S.; Bushnell, D.; Hura, G.L.; Koh, A.L.; Tsunoyama, H.; Tsukuda, T.; Pettersson, M.; Häkkinen, H.; et al. Electron microscopy of gold nanoparticles at atomic resolution. Science 2014, 345, 909-912. [CrossRef] [PubMed]

122. Nhat, P.V.; Si, N.T.; Nguyen, M.T. Structural Evolution and Stability Trend of Small-Sized Gold Clusters Aun ( $\mathrm{n}=20-30)$. J. Phys. Chem. A 2020, 124, 1289-1299. [CrossRef]

123. Reilly, S.M.; Krick, T.; Dass, A. Surfactant-free synthesis of ultrasmall gold nanoclusters. J. Phys. Chem. C 2010, 114, 741-745. [CrossRef]

124. Donkers, R.L.; Lee, D.; Murray, R.W. Synthesis and isolation of the molecule-like cluster Au38(PhCH2CH2S)24. Langmuir 2004, 20, 1945-1952. [CrossRef]

125. Barngrover, B.M.; Aikens, C.M. Electron and hydride addition to gold(I) thiolate oligomers: Implications for gold-thiolate nanoparticle growth mechanisms. J. Phys. Chem. Lett. 2011, 2, 990-994. [CrossRef]

126. Henglein, A.; Giersig, M. Formation of Colloidal Silver Nanoparticles: Capping Action of Citrate Arnim Henglein. J. Phys. Chem. B 1999, 103, 9533-9539. [CrossRef]

127. Ershov, B.G.; Janata, E.; Henglein, A.; Fojtik, A. Silver atoms and clusters in aqueous solution: Absorption spectra and the particle growth in the absence of stabilizing Ag+ ions. J. Phys. Chem. 1993, 97, 4589-4594. [CrossRef]

128. Liu, X.; Zhu, H. Strong Silver-Silver Interactions in Three Silver(I) Carboxylate Complexes with High Cytotoxicity Properties. Synth. React. Inorg. Met. Nano-Metal Chem. 2005, 35, 325-332. [CrossRef]

129. Bazhanova, Z.G.; Tarasov, Y.I.; Kovtun, D.M.; Boltalin, A.I.; Novosadov, B.K.; Kochikov, I.V. A quantum chemical study of the structure of fluorinated silver acetate(I) monomers and dimers. J. Struct. Chem. 2010, 51, 409-418. [CrossRef]

130. Jordan, A.J.; Lalic, G.; Sadighi, J.P. Coinage Metal Hydrides: Synthesis, Characterization, and Reactivity. Chem. Rev. 2016, 116, 8318-8372. [CrossRef]

131. Dubiel, M.; Brunsch, S.; Kolb, U.; Gutwerk, D.; Bertagnolli, H. Experimental studies investigating the structure of soda-lime glasses after silver-sodium ion exchange. J. Non-Cryst. Solids 1997, 220, 30-44. [CrossRef]

132. Loh, N.D.; Sen, S.; Bosman, M.; Tan, S.F.; Zhong, J.; Nijhuis, C.A.; Král, P.; Matsudaira, P.; Mirsaidov, U. Multistep nucleation of nanocrystals in aqueous solution. Nat. Chem. 2017. [CrossRef]

133. Wu, Z.; Suhan, J.; Jin, R. One-pot synthesis of atomically monodisperse, thiol-functionalized Au 25 nanoclusters. J. Mater. Chem. 2009, 19, 622-626. [CrossRef]

134. Creighton, J.A.; Blatchford, C.G.; Albrecht, M.G. Plasma resonance enhancement of Raman scattering by pyridine adsorbed on silver or gold sol particles of size comparable to the excitation wavelength. J. Chem. Soc. Faraday Trans. 2 Mol. Chem. Phys. 1979, 75, 790-798. [CrossRef] 